\title{
On the Importance of $\sigma$-Hole Interactions in Crystal Structures
}

\author{
Antonio Frontera *(D) and Antonio Bauzá *(D) \\ Departament de Química, Universitat de les Illes Balears, Crta. de Valldemossa km 7.5, \\ 07122 Palma de Mallorca (Baleares), Spain \\ * Correspondence: toni.frontera@uib.es (A.F.); antonio.bauza@uib.es (A.B.)
}

check for updates

Citation: Frontera, A.; Bauzá, A. On the Importance of $\sigma-$ Hole Interactions in Crystal Structures. Crystals 2021, 11, 1205. https://doi.org/10.3390/ cryst11101205

Academic Editors: Sergiy Rosokha and Atash V. Gurbanov

Received: 20 September 2021

Accepted: 6 October 2021

Published: 7 October 2021

Publisher's Note: MDPI stays neutral with regard to jurisdictional claims in published maps and institutional affiliations.

Copyright: (C) 2021 by the authors Licensee MDPI, Basel, Switzerland. This article is an open access article distributed under the terms and conditions of the Creative Commons Attribution (CC BY) license (https:// creativecommons.org/licenses/by/ $4.0 /)$.

\begin{abstract}
Elements from groups 14-18 and periods 3-6 commonly behave as Lewis acids, which are involved in directional noncovalent interactions (NCI) with electron-rich species (lone pair donors), $\pi$ systems (aromatic rings, triple and double bonds) as well as nonnucleophilic anions $\left(\mathrm{BF}_{4}{ }^{-}, \mathrm{PF}_{6}{ }^{-}\right.$, $\mathrm{ClO}_{4}{ }^{-}$, etc.). Moreover, elements of groups 15 to 17 are also able to act as Lewis bases (from one to three available lone pairs, respectively), thus presenting a dual character. These emerging NCIs where the main group element behaves as Lewis base, belong to the $\sigma$-hole family of interactions. Particularly (i) tetrel bonding for elements belonging to group 14, (ii) pnictogen bonding for group 15, (iii) chalcogen bonding for group 16, (iv) halogen bonding for group 17, and (v) noble gas bondings for group 18. In general, $\sigma$-hole interactions exhibit different features when moving along the same group (offering larger and more positive $\sigma$-holes) or the same row (presenting a different number of available $\sigma-$ holes and directionality) of the periodic table. This is illustrated in this review by using several examples retrieved from the Cambridge Structural Database (CSD), especially focused on $\sigma$-hole interactions, complemented with molecular electrostatic potential surfaces of model systems.
\end{abstract}

Keywords: $\sigma$-hole interactions; halogen bonding; chalcogen bonding; pnictogen bonding; tetrel bonding; noble gas bonding; crystal engineering

\section{Introduction}

Atoms from elements of groups 13-18 covalently bound to electron-withdrawing groups (EWGs) possess a strong ability to interact with Lewis bases (e.g., lone pair donors, anions, and $\pi$ systems) [1-13]. Since the electropositive site was used to define the hydrogen bonding (HB) interaction, scientists have started to use the name of the group to which the electrophilic atom belongs to name the noncovalent interactions (NCIs) between electrophilic and nucleophilic sites [14,15]. In fact, the International Union of Pure and Applied Chemistry (IUPAC) has already recommended the terms halogen bond (HaB) [16] and chalcogen bond (ChB) [17] for naming the NCIs involving atoms from groups 17 and 16, respectively. Furthermore, each group of the p-block possesses its own terminology, which are aerogen or noble gas bonding ( $\mathrm{NgB}$, group 18) [12], pnictogen bonding (PnB, group 15), [18,19] tetrel bonding (TtB, group 14) [20], and triel bonding (TrB, group 13) [7]. In addition, matere bonding (MaB, group 7) [21], osme bonding (OmB, group 8) [22], spodium bonding ( $\mathrm{SpB}$, group 12) [23], and regium or coinage bonding (CiB, group 11) have been used to refer to NCIs in which elements from groups 10 and 11 act as Lewis acids and to differentiate these types of interactions from classical coordination bonds [24-27].

In this regard, several studies have demonstrated that $\sigma$-holes (regions of positive electrostatic potential located on the extension of covalent bonds) can be used in a broad spectrum of fields, such as host-guest chemistry, catalysis, supramolecular chemistry, membrane transport, crystal engineering, etc. Noteworthy review articles, accounts, and book chapters are available in the literature describing promising applications and basic features of the $\sigma$-hole group of NCIs [28-45]. Moreover, several works have been devoted to the comparison of the geometric and energetic characteristics of $\sigma$-hole interactions to the HB [46-51]. 
A prototypical example of a $\sigma$-hole interaction is represented by the HaB shown in Figure 1, involving $\mathrm{CF}_{3} \mathrm{I}$ and water as $\mathrm{HaB}$ donor and acceptor counterparts. This concept experienced its naissance during the 20th century when HaBs started to be seen as the cause of several chemical phenomena. Concretely, Zingaro and Hedges [52] used the term halogen bond to refer to the interactions in which halogens act as electrophilic moieties while describing the formation of complexes in solution involving halogens and interhalogens with phosphine oxides and sulfides. Later, in 1976, Martire et al. [53] described the adducts formed in the gas phase by haloforms with ethers and amines, although in 1983, Dumas et al. [54] organized them under the term halogen bond. The term halogen bond began to increase its popularity after the manuscript reported by Metrangolo and Resnati, which proposed general and practical principles to correlate the structure of the $\mathrm{HaB}$ donor and acceptor moieties and the strength of the interaction [55]. During the past decade, the exponential growth in the interest of the scientific community has resulted in many experimental and theoretical studies being devoted to the analysis of HaBs [56-59]. In this context, the IUPAC project 2009-032-1-100 was started in 2009 with the mission to give a unified concept to interactions involving halogens as electrophilic species, and currently, it has been extended to the rest of the $\sigma$-hole family of interactions $[16,60]$. According to the IUPAC definition, a typical $\mathrm{HaB}$ is denoted as $\mathrm{R}-\mathrm{Ha} \cdots \mathrm{Y}$, with the three dots representing the bond. $\mathrm{R}-\mathrm{Ha}$ is the $\mathrm{HaB}$ donor, and $\mathrm{Ha}$ is a halogen atom covalently bound to the $\mathrm{R}$ group and having an electrophilic region, or a potentially electrophilic region, on its electrostatic potential surface ( $\sigma$-hole). On the other hand, $\mathrm{Y}$ is an electronrich atom that acts as a nucleophile ( $\mathrm{HaB}$ acceptor), such as a lone pair, an anion, or a $\pi$ system.

Two of the factors regulating the strength of the HaB (as well as other $\sigma$-hole-based interactions) are described below. Firstly, the polarizability of the atoms increases by descending the group of the periodic table. Hence, the electropositive region of the $\sigma$-hole consequently increases if the EWG-X bond is more polarized, thus resulting in a reinforcement of the NCI. Secondly, another way to polarize the EWG-X bond is by increasing the electron-withdrawing ability of EWG. Therefore, the combination of heavy elements and strong EWG increases the positive potential and size of the $\sigma$-hole, thus strengthening the NCI (i.e., the electrostatic term increases).

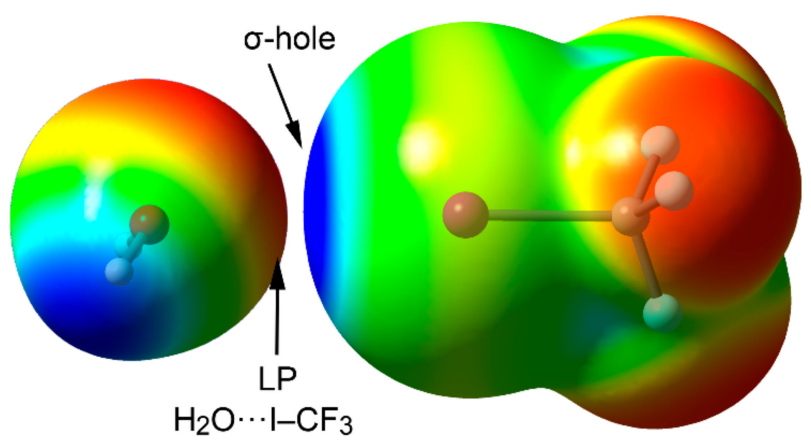

Figure 1. Graphical representation of a prototypical $\sigma$-hole complex between $\mathrm{H}_{2} \mathrm{O}$ and $\mathrm{ICF}_{3}$ molecules as electron donor and acceptor moieties, respectively. Electropositive regions are represented in blue and electronegative in red.

In recent years, the growing interest and increasing number of investigations in NCIs [61,62] involving elements of groups 14-18 have driven the creation and exploitation of new lines of research [14,15]. Many theoretical studies [36-46,61,62] have demonstrated that the distribution of electron density exhibits a marked anisotropy in $\mathrm{Ha}, \mathrm{Ch}$, and Pn elements owing to the coexistence of lone pairs and $\sigma$-holes on the same element. Particularly, in monovalent $\mathrm{Ha}$, divalent $\mathrm{Ch}$, trivalent $\mathrm{Pn}$, and tetravalent $\mathrm{Tt}$, the number of LPs varies from three to none, and the number of $\sigma$-holes from one to four On the other hand, for $\mathrm{NgO}_{3}$ molecules (group 18), an LP and three $\sigma$-holes are present, similarly to 
Pns (group 5). In all cases, the number and location of positive and negative electrostatic potential regions at the surface of these atoms correlate to the number and position of the covalent bonds the atoms are engaged in and the location of the lone pairs.

This review is organized as follows: First, we propose a general discussion on the variation of the $\sigma$-hole electrostatic potential and polarizability values of the elements belonging to a certain group, and second, we describe selected X-ray examples involving the heaviest elements of each group as representative cases. Further, at the end of each section, a Table gathers important information regarding the noncovalent partners involved in each $\mathrm{NCI}$, as well as their intermolecular distances and angles. Finally, it is also important to mention that this review is focused on the $\sigma$-hole family of interactions, and consequently, other NCIs also present in the X-ray crystal structures (e.g., hydrogen bonding) have not been described herein.

\section{Results and Discussion}

\subsection{Tetrel Bonding}

In Table 1, the polarizabilities $(\alpha)$ and van der Waals radii of the tetrel elements from periods 2 to 5 are gathered. As is evident, the atomic $\alpha$ value increases from 9.0 a.u. in C to 37.3 a.u. in Sn. Interestingly, there is a large gap in the atomic polarizability between $C$ and $\mathrm{Si}(\sim \times 3)$, and conversely, it is negligible between $\mathrm{Si}$ and $\mathrm{Ge}$ and negligible between $\mathrm{Ge}$ and Sn. The molecular electrostatic potential (MEP) values at the Tt $\sigma$-holes of the four fluoride derivatives included in this section are also given in Table 1, and the MEP surface of $\mathrm{SnF}_{4}$ is shown in Figure 2 as a representative case. The energetic data indicate that the MEP values increase when descending in the group, parallel to the behavior observed for the atomic polarizability.

Table 1. Atomic polarizabilities ( $\alpha$, a.u.) of tetrel (Tt) elements, van der Waals radii (in $\AA$ ) and $\sigma$-hole MEP values (in $\mathrm{kcal} / \mathrm{mol}$ ) of their tetrafluoride derivatives. Values are taken from ref [63].

\begin{tabular}{cccc}
\hline Tt & $\alpha$ & $\mathbf{R}_{\mathbf{v d W}}$ & MEP $\left(\mathbf{T t F}_{4}\right)$ \\
\hline $\mathrm{C}$ & 9.0 & 1.70 & 18.6 \\
\hline $\mathrm{Si}$ & 26.1 & 2.10 & 39.0 \\
\hline $\mathrm{Ge}$ & 28.4 & 2.11 & 50.2 \\
\hline $\mathrm{Sn}$ & 37.3 & 2.17 & 66.5 \\
\hline
\end{tabular}

Figure 2 shows the MEP surface of $\mathrm{SnF}_{4}$ as an illustrative example of the Tt series. As is evident, the $\sigma$-holes are small and well defined, thus anticipating a strong directionality of the TtB interaction. As mentioned above, the MEP value measured at the Sn $\sigma$-hole is the largest of the $\mathrm{Tt}$ series. Lastly, the strong and negative MEP values found at the F atoms confirm the strong polarization of the Sn-F bonds.

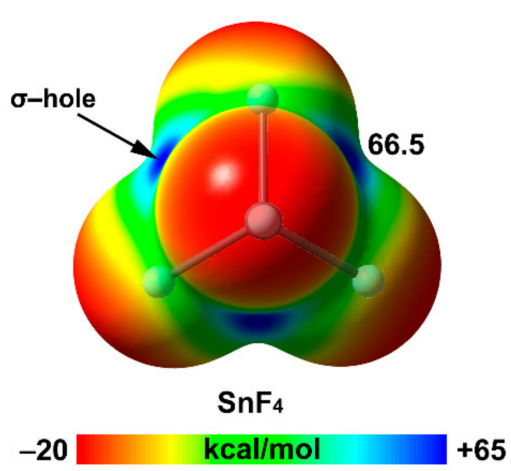

Figure 2. MEP surface of $\mathrm{SnF}_{4}$ using the 0.001 a.u. isosurface and the MP2/def2-TZVP level of theory (energy in $\mathrm{kcal} / \mathrm{mol}$ ). 
TtBs behave in a different way, compared with other $\sigma$-hole interactions, in terms of steric demands. That is, in a common $\mathrm{HaB}$ complex the Lewis base is separated by $180^{\circ}$ from the EWG covalently bound to the Ha atom; therefore, the bulkiness of the EWG does not influence the $\mathrm{HaB}$ interaction. Steric effects increase on moving from ChBs to TtBs, the former being similar to HaBs in terms of sterical features. In the case of PnBs and $\mathrm{NgBs}$, the electron-rich atom is, in most cases, able to approach the $\mathrm{Pn} / \mathrm{Ng}$ atom without substantial steric repulsion. The situation is quite different in $\mathrm{Tt}$ atoms since the tetrahedral spacing of its four substituents augments the steric crowding and, simultaneously, increases the steric repulsion with the electron-rich atom. This aspect is very important in TtBs and has been studied in detail [63], focusing on the size of the Tt atom (from Si to Pb), the size and electron-withdrawing ability of the substituents, and the type of electron-rich atom (neutral or charged).

\section{Germanium and Tin}

A great number of experimental and theoretical investigations involving TtBs [2,20,64,65] are concentrated on the lighter elements (carbon and silicon), while those studying the heavier tetrels are scarcer [66-69]. Nevertheless, two excellent reviews are available including several X-ray crystal structures that prove the ability of $\mathrm{Ge}, \mathrm{Sn}$ to establish highly directional interactions [70,71], which are key for assembling the crystal packing of many germanium and tin derivatives. These reviews report that TtBs exhibit a higher directionality than PnBs and ChBs and are similar to HaBs.

Two examples of X-ray structures exhibiting directional $\mathrm{Ge} \cdots \mathrm{O}$ and $\mathrm{Ge} \cdots \mathrm{F}$ TtBs are highlighted in Figures 3 and 4. The first one is propagated along a direction of the crystal, thus forming infinite 1D supramolecular chains through highly directional TtBs (QAHXIG) [72], where the most polarized covalent bond $\left(\mathrm{O}_{2} \mathrm{SC}-\mathrm{Ge}\right)$ interacts with the sulfonyl oxygen atom of the adjacent molecule. This interaction possesses a Ge...O distance of $3.520 \AA$ and $\mathrm{C}-\mathrm{Ge} \cdots \mathrm{O}$ angle of $179.8^{\circ}$, in line with the strong linearity expected for TtBs.

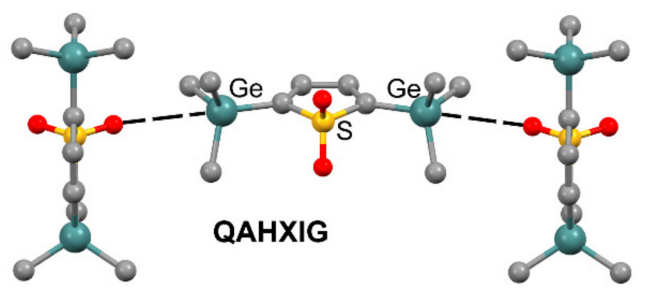

Figure 3. Ball-and-stick representation of the solid state of QAHXIG structure [69] showing the $\mathrm{C}-\mathrm{Ge} \cdots \mathrm{O}$ TtBs that are represented using dashed lines. H atoms omitted for clarity.

In Figure 4, the X-ray structure of $\left[\mathrm{Ge}_{8} \mathrm{O}_{12}(\mathrm{OH})_{8} \mathrm{~F}^{-}\right.$cluster (VUZVUH) [70] is represented in which the $\mathrm{Ge}_{8} \mathrm{O}_{12}(\mathrm{OH})_{8}$ fragment presents a cuboidal structure, with the fluoride anion encapsulated in the center, establishing eight directional TtBs (see Table 2), where the $\mathrm{F}$ is situated opposite to the $\mathrm{Ge}-\mathrm{O}$ bonds. As previously demonstrated [20], in this type of cubanes, the eight $\sigma$-holes merge in the center of the cube, generating a macro $\sigma$-hole in which only small anions fit inside.

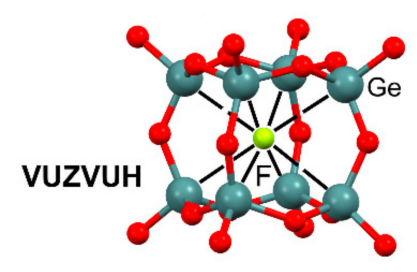

Figure 4. Ball-and-stick representation of the solid state of VUZVUH structure [73] highlighting the $\mathrm{O}-\mathrm{Ge} \cdots \mathrm{F}$ TtBs, which are represented using dashed lines. H atoms omitted for clarity.

In the case of Tin, two X-ray examples have been selected and characterized by the formation of infinite 1D supramolecular chains in the solid state. In both structures, the 
LP-donor atom interacts with the $\mathrm{Sn}$ atom opposite to the most polarized bond, $\mathrm{Sn}-\mathrm{F}$ in BAJWOY [74] and $\mathrm{Sn}-\mathrm{Cl}$ in BIBQIN [75] (see Table 2 for distances and angles). In the latter structure, the tetrel atom of the chlorotris(4-cyanobenzyl)tin molecule undergoes a very short $\mathrm{Sn} \cdots \mathrm{N}$ TtB, especially considering that the sp-hybridized $\mathrm{N}$ atom of the cyano group is a poor electron donor. Similar behavior is observed in tricyclohexyltin fluoride (BAJWOY, Figure $5 \mathrm{a}$ ), where a short $\mathrm{TtB}$ is established between a fluorine atom of one molecule and the Sn $\sigma$-hole from the covalent $\mathrm{Sn}-\mathrm{F}$ bond of an adjacent molecule, thus propagating the infinite chains despite the poor Lewis basicity of the F atom. Therefore, the quite short TtBs are likely due to the strong $\sigma$-hole donor ability of Sn, in good agreement with the MEP surface shown in Figure 2.

(a)

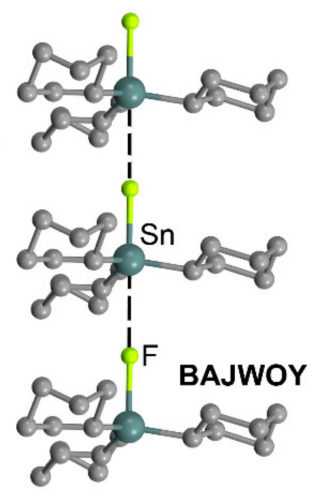

(b)

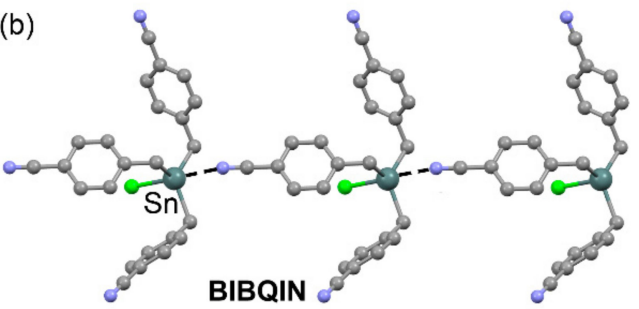

Figure 5. Ball-and-stick representation of BAJWOY (a) and BIBQIN (b) structures exhibiting $\mathrm{F}, \mathrm{Cl}-\mathrm{Sn} \cdots \mathrm{F}$ and $\mathrm{Sn} \cdots \mathrm{N}$ TtBs, which are represented using dashed lines. $\mathrm{H}$ atoms omitted for clarity.

Table 2. CSD codes, $\mathrm{TtB}$ donor $(\mathrm{Tt})$, and acceptor $(\mathrm{A})$ atoms, intermolecular distance $\left(\mathrm{d}_{\mathrm{Tt} \ldots \mathrm{A}}\right.$ in $\AA$ ), and $\mathrm{X}-\mathrm{Tt} \cdots \mathrm{A}(\mathrm{X}=\mathrm{C}, \mathrm{O}, \mathrm{F}$ and $\mathrm{Cl})$ angle $\left(\angle \mathrm{in}^{\circ}\right)$.

\begin{tabular}{ccccc}
\hline CSD Code & Tt & $\mathbf{A}$ & $\mathbf{d}_{\mathbf{T t} \cdots \mathbf{A}}$ & \multicolumn{1}{c}{} \\
\hline QAHXIG & $\mathrm{Ge}$ & $\mathrm{O}$ & 3.520 & 179.8 \\
\hline VUZVUH & $\mathrm{Ge}$ & $\mathrm{F}$ & $2.736-2.778$ & $173.8-174.3$ \\
\hline BAJWOY & $\mathrm{Sn}$ & $\mathrm{F}$ & 3.321 & 178.9 \\
\hline BIBQIN & $\mathrm{Sn}$ & $\mathrm{N}$ & 2.926 & 175.1 \\
\hline
\end{tabular}

\subsection{Pnictogen Bonding}

A plethora of theoretical works dealing with PnBs are available in the literature $[43,44,76-83]$. However, those presenting experimental evidence are much less common [84-89]. Nevertheless, this interaction has been recently proposed for the design and synthesis of supramolecular catalysts by Matile et al. [90]. Several noteworthy reviews are available in the literature, indicating the relevance of PnBs in the gas and solid states. In fact, this interaction has been used as a consistent tool in crystal engineering [43,44,91-93].

Table 3 summarizes the polarizabilities $(\alpha)$ and van der Waals radii of the pnictogen elements from periods 2 to 5 . The atomic $\alpha$ value increases from 5.3 a.u. in $\mathrm{N}$ to 30.8 a.u. in $\mathrm{Sb}$. As also observed for tetrels, the difference in the atomic polarizability between the elements of groups 2 and 3 is quite large $(\sim \times 3)$ and small for elements of groups 3 and 4 . The difference is again important between $\mathrm{As}$ and $\mathrm{Sb}$. Compared with tetrel atoms, the pnictogen atoms are less polarizable and exhibit smaller van der Waals radii. The MEP values at the $\sigma$-holes of the fluoride derivatives of the four Pn elements studied in this section are also included in Table 3 and that for $\mathrm{SbF}_{3}$ is represented in Figure 6. The energetic data indicate that the MEP values at the $\sigma$-hole become more positive when descending in the group, in a parallel way to the tendency observed for the tetrels (see Section 2.1). 
Table 3. Atomic polarizabilities ( $\alpha$, a.u.) of pnictogen (Pn) elements, van der Waals radii (in $\AA$ ), and $\sigma$-hole MEP values (in $\mathrm{kcal} / \mathrm{mol}$ ) of their tetrafluoride derivatives. Data extracted from ref [63].

\begin{tabular}{cccc}
\hline Pn & $\alpha$ & $\mathbf{R}_{\mathbf{v d W}}$ & MEP (PnF $\mathbf{3}$ \\
\hline $\mathrm{N}$ & 5.3 & 1.55 & 15.9 \\
\hline $\mathrm{P}$ & 16.9 & 1.80 & 27.4 \\
\hline $\mathrm{As}$ & 21.6 & 1.85 & 38.5 \\
\hline $\mathrm{Sb}$ & 30.8 & 2.06 & 46.7 \\
\hline
\end{tabular}

Figure 6 shows the MEP surfaces of $\mathrm{SbF}_{3}$ as an illustrative example of the pnictogen series. As can be observed, the $\mathrm{SbF}_{3}$ molecule presents a wide region of positive potential where the global maximum is located approximately opposite to the $\mathrm{Sb}-\mathrm{F}$ bonds. Hence, it is expected that PnBs involving the heavier Pn atoms present a lesser directionality compared to TtBs. As also observed for the $\mathrm{SbF}_{3}$ molecule, the large and negative MEP values at the $\mathrm{F}$ atoms reveal that the $\mathrm{Sb}-\mathrm{F}$ bonds are strongly polarized. Finally, it is also worth noting that the MEP values at the $\sigma$-holes are greater for tetrel atoms than for pnictogen ones (see Tables 1 and 3), in agreement with the atomic polarizabilities.

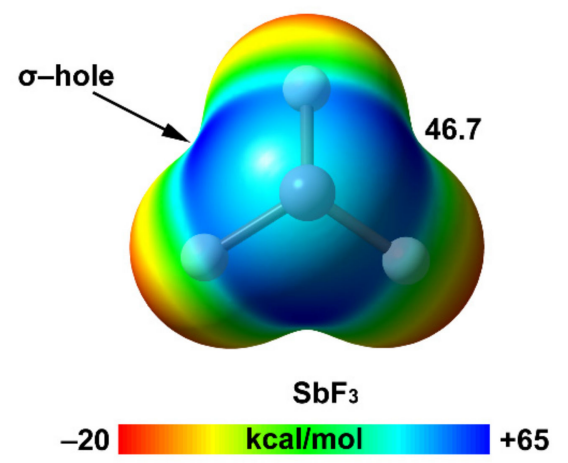

Figure 6. MEP surfaces of $\mathrm{SbF}_{3}$ using the 0.001 a.u. isosurface and the MP2/def2-TZVP level of theory (energy in $\mathrm{kcal} / \mathrm{mol}$ ).

\section{Arsenic and Antimony}

As mentioned above, these two elements undertake stronger PnBs than $\mathrm{N}$ and $\mathrm{P}$. Precisely, their use in supramolecular catalysis [94,95] and anion recognition [96] has been recently demonstrated. Among the heavier pnictogens, antimony is the most promising pnictogen atom to be used in supramolecular chemistry and, particularly, for the recognition of anions. In this context, Gabbaï et al. have successfully used bis-stilbonium to build a preorganized host [97] including two strong $\sigma$-hole donors that establish several PnB interactions with electron-rich guests. Additionally, Cozzolino et al. have also synthesized anion receptors based on bidentate anion-binding motifs containing two $\mathrm{Sb}$ (III) centers bridged by either oxygen or sulfur atoms as PnB donors [98].

Figure 7 includes the $X$-ray structures of the inorganic salts $\mathrm{As}\left(\mathrm{N}_{3}\right)_{3}$ and $\mathrm{Sb}\left(\mathrm{N}_{3}\right)_{3}$ structures (ICSD413360 and ICSD413359 [99], respectively) to illustrate the ability of As(III) and $\mathrm{Sb}$ (III) derivatives to establish three simultaneous PnBs by using the three available $\sigma$-holes on the antimony atom. In the solid state, each molecule interacts with the electron-rich group (azide) of three adjacent molecules, thus being crucial for driving the 3D architecture formation of these inorganic salts. The three PnBs are symmetrically equivalent in the $\mathrm{Sb}\left(\mathrm{N}_{3}\right)_{3}$ compound and thus exhibit a worse directionality than the $\mathrm{As}\left(\mathrm{N}_{3}\right)_{3}$ compound (see Table 4 for distances and angles). 
(a)

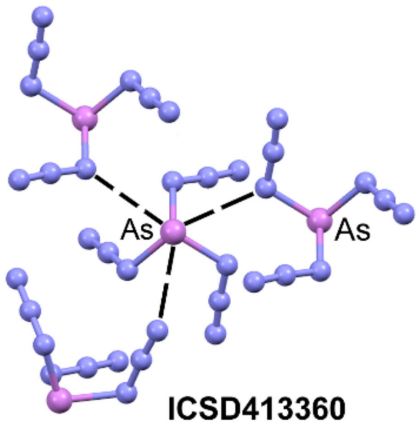

(b)

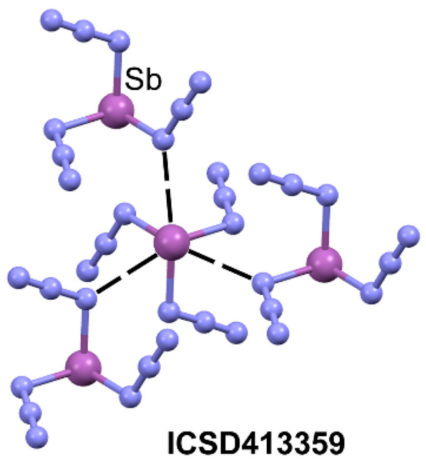

Figure 7. Ball-and-stick representation of ICSD413360 (a) and ICSD413359 (b) structures exhibiting PnBs, which are represented using dashed lines.

In parallel to $\mathrm{As}\left(\mathrm{N}_{3}\right)_{3}$, tricyano-arsenic(III) also undergoes three simultaneous PnBs, with three adjacent molecules in the crystal structure (USEPUF [100], see Figure 8a) with short distances and C-As $\cdots \mathrm{N}$ angles comprised between $161^{\circ}$ to $162^{\circ}$ (see Table 4). Two additional examples of Pn $\cdots$ O contacts are included in Figure 8b,c. In UROZIL [101] structure the arsenium atom establishes three short PnBs with the neighboring phosphine oxide groups with $\mathrm{F}-\mathrm{As} \cdots \mathrm{O}$ angles ranging from $167^{\circ}$ to $177^{\circ}$. Remarkably, two pyramidal $\mathrm{SbF}_{3}$ units in UROYUW [101] establish two short PnB contacts with two bridging diphosphine dioxides, thus forming a 12-membered supramolecular ring.

(a)

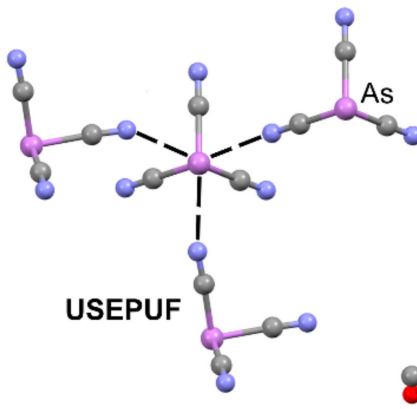

(b)

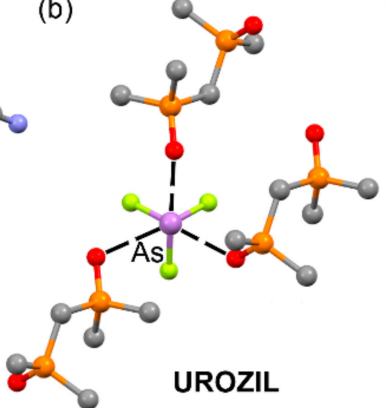

(c)

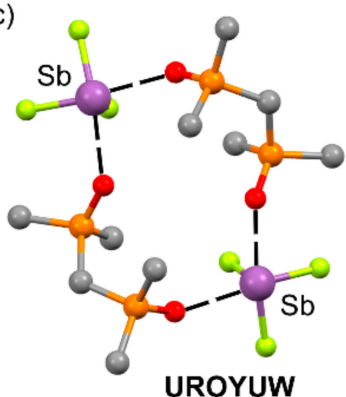

Figure 8. Ball-and-stick representation of the solid-state X-ray structures of USEPUF (a), UROZIL (b), and UROYUW (c) structures. The PnBs are represented using dashed lines. $\mathrm{H}$ atoms omitted for clarity.

In the case of USEQAM [100] structure, the tricyano-antimony(III) is co-crystallized with 2,2'-bipyridine (Figure 9) and exhibits two very short PnBs between the $\mathrm{N}$ atoms of bipyridine and $\mathrm{Sb}(2.724$ and $2.560 \AA)$. The third PnB is significantly longer, and it involves the $\mathrm{N}$ atom of the cyano group of the adjacent molecule. The quite different PnBs distances observed in this compound agree well with the relative basicity of the $\mathrm{N}$-donor atoms. This combination of PnBs regulates the formation of infinite 1D supramolecular assemblies in the solid state. In general, the angles observed for the PnBs gathered in Table 4 are less directional than those described for tetrel bonding interactions (see Table 3). This result is in agreement with the MEP surface plots shown in Figures 2 and 6 that point to larger and more accessible $\sigma$-holes in $\mathrm{SbF}_{3}$ than in $\mathrm{SnF}_{4}$. 


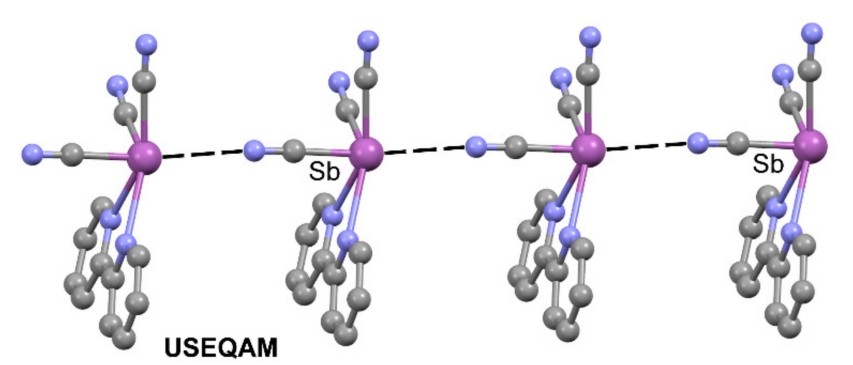

Figure 9. Ball-and-stick representation of the solid state of USEQAM structure showing the 1D infinite assembly. The PnBs are represented using dashed lines. $\mathrm{H}$ atoms omitted for clarity.

Table 4. CSD codes, PnB donor (Pn) and acceptor $(A)$ atoms, intermolecular distance $\left(\mathrm{d}_{\mathrm{Pn} \cdots \mathrm{A}}\right.$ in $\AA$ ), and $\mathrm{X}-\mathrm{Pn} \cdots \mathrm{A}(\mathrm{X}=\mathrm{N}$ and $\mathrm{O})$ angle $\left(\angle\right.$ in $\left.{ }^{\circ}\right)$.

\begin{tabular}{ccccc}
\hline CSD Code & Pn & $\mathbf{A}$ & $\mathbf{d}_{\mathbf{P n} \cdots \mathbf{A}}$ & \multicolumn{1}{c}{ 157.7-164.1 } \\
\hline ICSD413360 & $\mathrm{As}$ & $\mathrm{N}$ & $2.978-3.198$ & 149.9 \\
\hline ICSD413359 & $\mathrm{Sb}$ & $\mathrm{N}$ & 2.844 & $161.5-162.4$ \\
\hline USEPUF & $\mathrm{As}$ & $\mathrm{N}$ & $2.794-2.837$ & $167.6-176.8$ \\
\hline UROZIL & $\mathrm{As}$ & $\mathrm{O}$ & $2.575-2.965$ & $161.5-168.0$ \\
\hline UROYUW & $\mathrm{Sb}$ & $\mathrm{O}$ & $2.446-2.455$ & 170.3 \\
\hline USEQAM & $\mathrm{Sb}$ & $\mathrm{N}$ & 3.412 &
\end{tabular}

\subsection{Chalcogen Bonding}

In recent years, noticeable progress has been made in the supramolecular chemistry of chalcogen bonding, particularly in controlling and tuning new chemical systems for applications in crystal engineering, supramolecular chemistry, catalysis, transport of anions, and functional materials $[3,9,10,42]$.

In Table 5, the polarizabilities $(\alpha)$ and van der Waals radii of the chalcogen elements from periods 2 to 5 are gathered. As can be inferred, the atomic $\alpha$ value increases from 3.0 a.u. in $\mathrm{O}$ to 25.9 a.u. in Te. Interestingly, the difference in the atomic polarizability between $\mathrm{O}$ and $\mathrm{S}$ is quite large $(\sim \mathrm{x} 4)$, in line with the behavior observed in $\mathrm{Tt}$ and $\mathrm{Pn}$ atoms. On the contrary, the differences between $S$ and Se or Se and Te are very small. The MEP values at the $\sigma$-holes of the fluoride derivatives of the four Ch elements studied in this section are also given in Table 5, and the MEP for the $\mathrm{TeF}_{2}$ molecule is represented in Figure 10. They show the expected trend with $\sigma$-hole values increasing from $16.8 \mathrm{kcal} / \mathrm{mol}$ in $\mathrm{OF}_{2}$ to $52.6 \mathrm{kcal} / \mathrm{mol}$ in $\mathrm{TeF}_{2}$. Compared with $\mathrm{TtF}_{4}$ and $\mathrm{PnF}_{3}$ compounds, the MEP values in $\mathrm{ChF}_{2}$ molecules are lower, showing that the Lewis acidity is progressively reduced on going from group 14 to 16 .

Table 5. Atomic polarizabilities ( $\alpha$, a.u.) of chalcogen (Ch) elements, van der Waals radii (in $\AA$ ), and $\sigma$-hole MEP values (in $\mathrm{kcal} / \mathrm{mol}$ ) of their tetrafluoride derivatives taken from ref [63].

\begin{tabular}{cccc}
\hline Ch & $\boldsymbol{\alpha}$ & $\mathbf{R}_{\mathbf{v d W}}$ & MEP $\left(\mathbf{C h F}_{\mathbf{2}}\right)$ \\
\hline $\mathrm{O}$ & 3.0 & 1.52 & 16.8 \\
\hline $\mathrm{S}$ & 11.8 & 1.80 & 35.6 \\
\hline $\mathrm{Se}$ & 17.5 & 1.90 & 44.9 \\
\hline $\mathrm{Te}$ & 25.9 & 2.06 & 52.6 \\
\hline
\end{tabular}

Figure 10 shows the MEP surfaces of $\mathrm{TeF}_{2}$ as an illustrative example of the whole series. As is evident, $\mathrm{TeF}_{2}$ exhibits an extended region of positive MEP values in the molecular plane with two $\sigma$-holes located approximately on the extension of the F-Te bonds, thus 
anticipating worse directionality for the heavier chalcogen atoms. Similar behavior is observed in pnictogen fluorides (see Figure 6). Contrariwise, all tetrel elements (from $C$ to $\mathrm{Sn}$ ) present well-defined $\sigma$-hole regions (see Figure 2 for $\mathrm{SnF}_{4}$ representation) and form highly directional interactions.

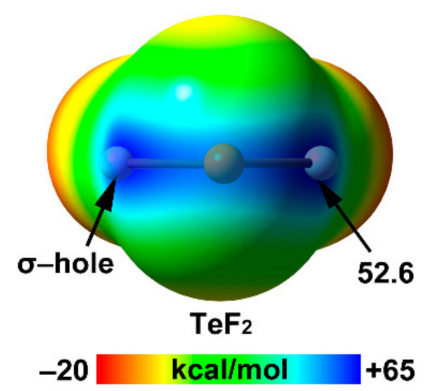

Figure 10. MEP surfaces of $\mathrm{TeF}_{2}$ using the 0.001 a.u. isosurface and the MP2/def2-TZVP level of theory (energy in $\mathrm{kcal} / \mathrm{mol}$ ).

\section{Selenium and Tellurium}

Selenium is a critical trace element $[102,103]$ with an increasing number of investigations [104-106]. Its derivatives are considered of great importance in the pharmaceutical industry, and several review articles $[9,40,41]$ are available in the literature devoted to the study of organoselenium compounds and their interactions with electron-rich species. Particularly, many studies demonstrate the ability of organic diselenides to establish both intermolecular and intramolecular $\mathrm{ChBs}$ with electron-rich atoms, which are stronger and more directional (see Table 6 for geometrical details) in the prolongation of the Se-Se bond [9]. Two examples are shown in Figures 11 and 12, the first one illustrating ChBs in the prolongation of the diselenide bond (FEYBAP [107]).

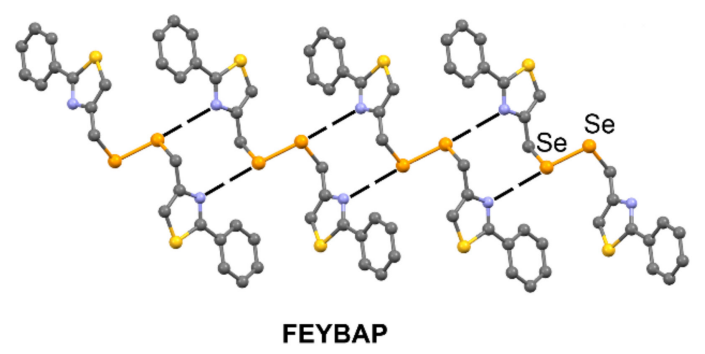

Figure 11. Ball-and-stick representation of the X-ray solid-state structure of FEYBAP showing the ChBs represented using dashed lines. $\mathrm{H}$ atoms omitted for clarity.

In Figure 12, the HOGBOW [108] crystal architecture is shown, exhibiting ChBs in the middle of the Se-Se bond, because of the overlapping of both $\sigma$-holes. See Table 6 for geometrical details.

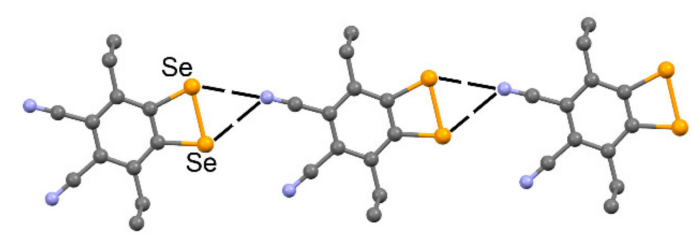

\section{HOGBOW}

Figure 12. Ball-and-stick representation of the X-ray solid-state structure of HOGBOW showing the 1D supramolecular polymer. The ChBs are represented using dashed lines. $\mathrm{H}$ atoms omitted for clarity. 
Two recent examples of directional and structure guiding ChBs in selenodiazoles are represented in Figure 13. The SAJPAY and SAJQED [109] structures correspond to the cocrystals of 3,4-dicyano-1,2,5-selenodiazole with p-methoxypyridine- $\mathrm{N}$-oxide and p-phenylpyridine-N-oxide, respectively. Both structures present the same binding pattern, thus showing double ChB interactions in the cocrystals forming four-membered supramolecular rings (Figure 13a,b).
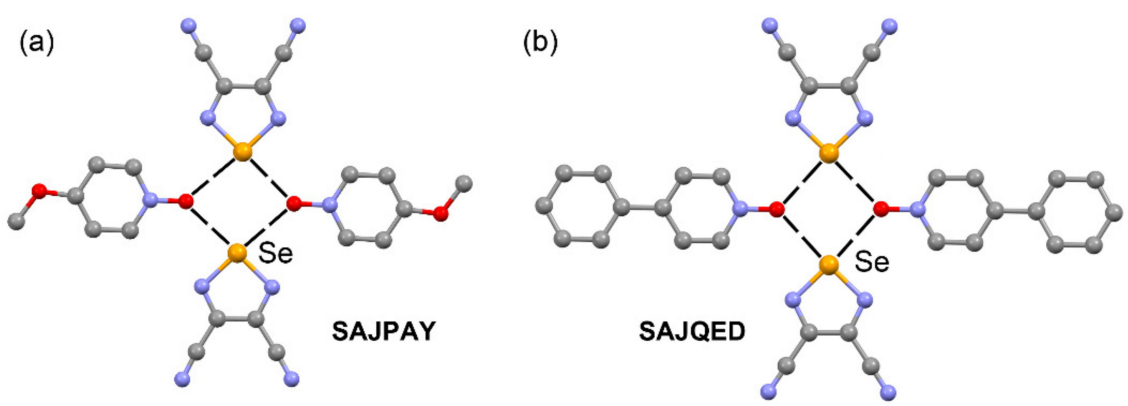

Figure 13. Ball-and-stick representation of the X-ray solid-state structures of SAJPAY (a), SAJQED (b) showing the $\mathrm{ChBs}$ that are represented using dashed lines. $\mathrm{H}$ atoms omitted for clarity.

To further showcase the importance of Se as a $\sigma$-hole donor, the X-ray structure of 2,2'-(benzo[1,2,5]selenadiazole)-4,8-diylidene)dimalononitrile (GEFVOC10 [110]) is given in Figure 14a. It presents a planar geometry, and the Se atoms behave as double ChB donors toward the $\mathrm{N}$ atoms of the adjacent cyano groups with a noticeable directionality $\left(169.5^{\circ}\right.$, see Table 6). These short ChBs involve a molecule with its four nearest neighbors (Figure 14a), driving the formation of infinite 2D supramolecular assemblies. In addition, the cocrystal of 18-crown-6 with selenium dicyanide (QUHYAV [108]) is represented in Figure 14b. It shows two short and moderately directional ChBs (geometric details in Table 6) that are established opposite to both electron-withdrawing cyano groups, therefore confirming the $\sigma$-hole nature of the interaction.

(a)

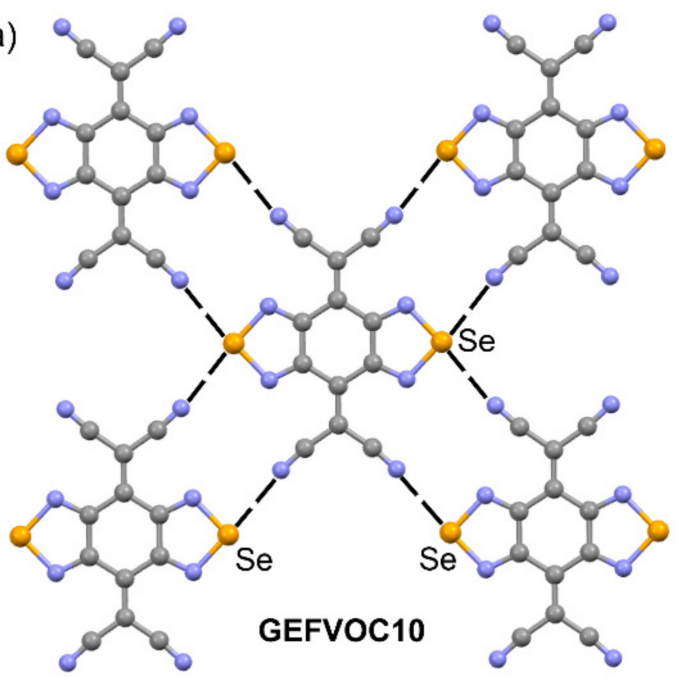

(b)

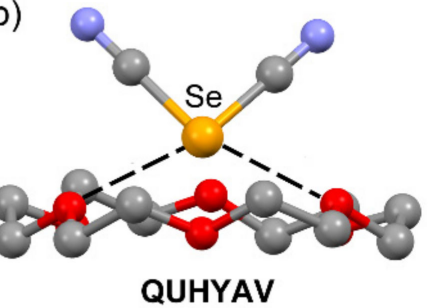

Figure 14. Ball-and-stick representation of the X-ray solid-state structures of GEFVOC10 (a) and QUHYAH (b). The ChBs are represented using dashed lines. $\mathrm{H}$ atoms omitted for clarity.

On the other hand, organotellurium compounds such as tellurophene and bis(tellurophene) derivatives usually present large and deep $\sigma$-holes even without the presence of strong EWGs bonded to the Te atom. Therefore, they are gaining interest in solution states to be used in supramolecular catalysis and anion recognition phenomena [11,111-113]. A noteworthy review providing a survey of tellurium-centered 
secondary-bonding supramolecular synthons is already available in the literature [114]. Furthermore, several theoretical investigations have reported that Se and Te are able to form very strong ChBs $[115,116]$.

Figure 15 shows two selected examples of ChBs involving Te. In the first one (CISPUP [117]), a head-to-tail arrangement is formed in the solid-state structure of bis(thiobenzoatoS)-tellurium, where each Te atom is involved in double ChBs with the $\mathrm{S}$ atoms of the adjacent molecule, thus generating an infinite 1D supramolecular column (Figure 15a). In the second one, phenanthro(9,10-c)-1,2,5-telluradiazole (FELPUH [118]) self-assembles, forming dimers in the crystal packing through two short and symmetrically equivalent $\mathrm{Te} \cdots \mathrm{N}$ ChBs (Figure 15b). The directionality of the ChBs is in general moderate in the two structures represented in Figure 15 (see Table 6). This fact is in agreement with the MEP surface of $\mathrm{TeF}_{2}$ that shows extended and deep $\sigma$-holes, thus allowing larger rearrangements and readjustments of the geometries in these molecules owing to the influence of secondary interactions and packing effects without a significant weakening of the ChB.

(a)

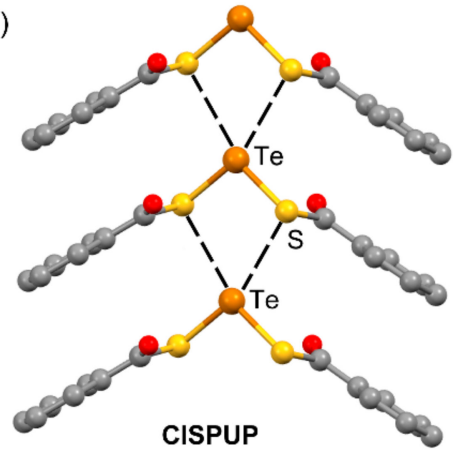

(b)

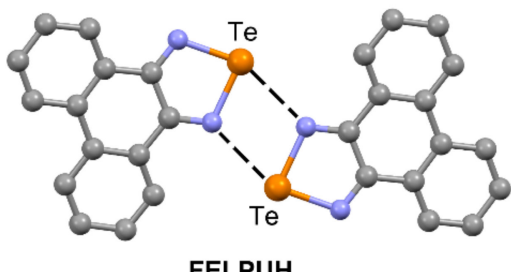

FELPUH

Figure 15. Ball-and-stick representation of the X-ray solid-state structures of CISPUP (a) and FELPUH (b), where the $\mathrm{ChBs}$ are represented using dashed lines. $\mathrm{H}$ atoms omitted for clarity.

Table 6. CSD codes, $\mathrm{ChB}$ donor $(\mathrm{Ch})$ and acceptor $(\mathrm{A})$ atoms, intermolecular distance $\left(\mathrm{d}_{\mathrm{Ch} \cdots \mathrm{A}}\right.$ in $\AA$ ), and $\mathrm{X}-\mathrm{Ch} \cdots \mathrm{A}(\mathrm{X}=\mathrm{N}, \mathrm{O}$, and $\mathrm{S})$ angle $\left(\angle\right.$ in $\left.^{\circ}\right)$.

\begin{tabular}{ccccc}
\hline CSD Code & $\mathbf{C h}$ & $\mathbf{A}$ & $\mathbf{d}_{\mathbf{C h} \cdots \mathbf{A}}$ & \multicolumn{1}{c}{} \\
\hline FEYBAP & Se & $\mathrm{N}$ & 3.342 & 171.9 \\
\hline HOGBOW & $\mathrm{Se}$ & $\mathrm{N}$ & $3.049-3.124$ & $140.2-144.2$ \\
\hline SAJPAY & $\mathrm{Te}$ & $\mathrm{O}$ & $2.076-2.784$ & $173.8-176.3$ \\
\hline SAJQED & $\mathrm{Te}$ & $\mathrm{O}$ & $2.756-2.758$ & $172.6-174.7$ \\
\hline GEFVOC10 & $\mathrm{Se}$ & $\mathrm{N}$ & 2.940 & 169.5 \\
\hline QUHYAV & $\mathrm{Se}$ & $\mathrm{O}$ & 2.938 & $161.2-167.3$ \\
\hline CISPUP & $\mathrm{Te}$ & $\mathrm{S}$ & 3.409 & 161.5 \\
\hline FELPUH & $\mathrm{Te}$ & $\mathrm{N}$ & 2.825 & 150.9 \\
\hline
\end{tabular}

\subsection{Halogen Bonding}

The halogen bonding interaction is likely the most studied and reviewed noncovalent interaction after the ubiquitous hydrogen bonding [29-39]. Remarkably, the seminal HaB has inspired the scientific community to further investigate and rationalize the ability of the other elements of the p-block to form analogous $\mathrm{ChB}, \mathrm{PnB}, \mathrm{TtBs}$, and $\mathrm{NgBs}$ and to expand the $\sigma$-hole concept. Since there is a considerable amount of information available for the readers in the form of reviews and book chapters devoted to HaB [29-39], this interaction is briefly described in this section of the present review.

Table 7 summarizes the polarizabilities $(\alpha)$ and van der Waals radii of the halogen elements from periods 2 to 5 . The atomic $\alpha$ value increases from 1.8 a.u. in F to 22.6 a.u. in 
I. In line with the Ch elements, the difference in the atomic polarizability between $\mathrm{F}$ and $\mathrm{Cl}$ is quite large $(\sim \mathrm{x} 4)$, while the differences between the rest of the elements are much smaller. The MEP values at the $\sigma$-holes of the fluoride derivatives of the four Ha elements studied in this section are also given in Table 7, and the MEP surface of IF is represented in Figure 16. They show the expected behavior, increasing from $15.9 \mathrm{kcal} / \mathrm{mol}$ in $\mathrm{F}_{2}$ to $55.8 \mathrm{kcal} / \mathrm{mol}$ in IF, parallel to the behavior observed for the atomic polarizability values.

Table 7. Atomic polarizabilities ( $\alpha$, a.u.) of halogen (Ha) elements, van der Waals radii (in A,) and $\sigma$-hole MEP values (in $\mathrm{kcal} / \mathrm{mol}$ ) of their tetrafluoride derivatives taken from ref [63].

\begin{tabular}{cccc}
\hline Ha & $\boldsymbol{\alpha}$ & $\mathbf{R}_{\mathbf{v d W}}$ & MEP (HaF) \\
\hline $\mathrm{F}$ & 1.8 & 1.47 & 15.9 \\
\hline $\mathrm{Cl}$ & 8.4 & 1.75 & 42.3 \\
\hline $\mathrm{Br}$ & 14.0 & 1.89 & 49.7 \\
\hline $\mathrm{I}$ & 22.6 & 1.98 & 55.8 \\
\hline
\end{tabular}

Figure 16 shows the MEP surface of IF as an illustrative example of the whole series. As can be observed, the $\sigma$-hole is small and well-defined opposite to the I-F bond, thus predicting stronger directionality in $\mathrm{HaB}$, in comparison to $\mathrm{ChB}$ or $\mathrm{PnB}$ and similar to $\mathrm{TtBs}$ that also showed well-defined $\sigma$-hole regions (see Figure 2).

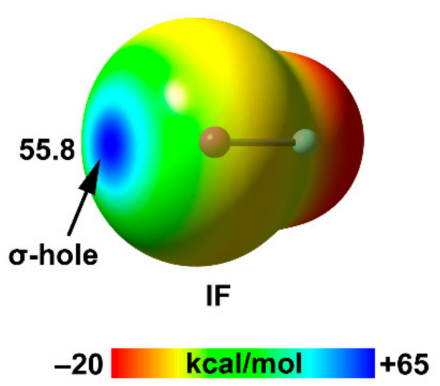

Figure 16. MEP surfaces of IF using the 0.001 a.u. isosurface and the MP2/def2-TZVP level of theory (energy in $\mathrm{kcal} / \mathrm{mol}$ ).

\section{Bromine and Iodine}

HaBs involving bromine and iodine as $\sigma$-hole donors have been used in a wide variety of fields, including crystal engineering, catalysis, supramolecular chemistry, molecular recognition of anions, and membrane transport [28-39,47-51]. Therefore, this section is devoted to discussing more unconventional and recent investigations on halogen bonding in which the Lewis base is a transition metal complex. That is the $d_{\mathrm{z}}^{2}[\mathrm{M}]$ orbital in a square planar or the $d_{\mathrm{x}}^{2}-\mathrm{y}^{2}[\mathrm{M}]$ in a linear two coordinated complex act as electron donor instead of a more conventional Lewis base (see Figure 17).

Commonly used $\mathrm{HaB}$ acceptors (electron donors) are lone pair (LP) bearing atoms such as nitrogen, phosphorus, oxygen, sulfur, and halogens. Furthermore, electron-rich $\mathrm{C}$ atoms $\left(\mathrm{CO}, \mathrm{CN}^{-}, \mathrm{RCC}^{-}\right)$and $\pi$ systems $(-\mathrm{C}=\mathrm{C}-;-\mathrm{C} \equiv \mathrm{C}-$, arene $)$ are also used as $\mathrm{HaB}$ acceptors. On the contrary, a counterintuitive vision is using a filled $d_{\mathrm{z}}{ }^{2}$-orbital as $\mathrm{HaB}$ acceptor in a positively charged metal center. Metal can act as an electron donor if it contains at least one LP, which could interact with the empty $\sigma$-hole of the HaB. In recent times, several investigations have utilized such uncommon HaBs in crystal engineering and supramolecular chemistry $[116,117]$. 


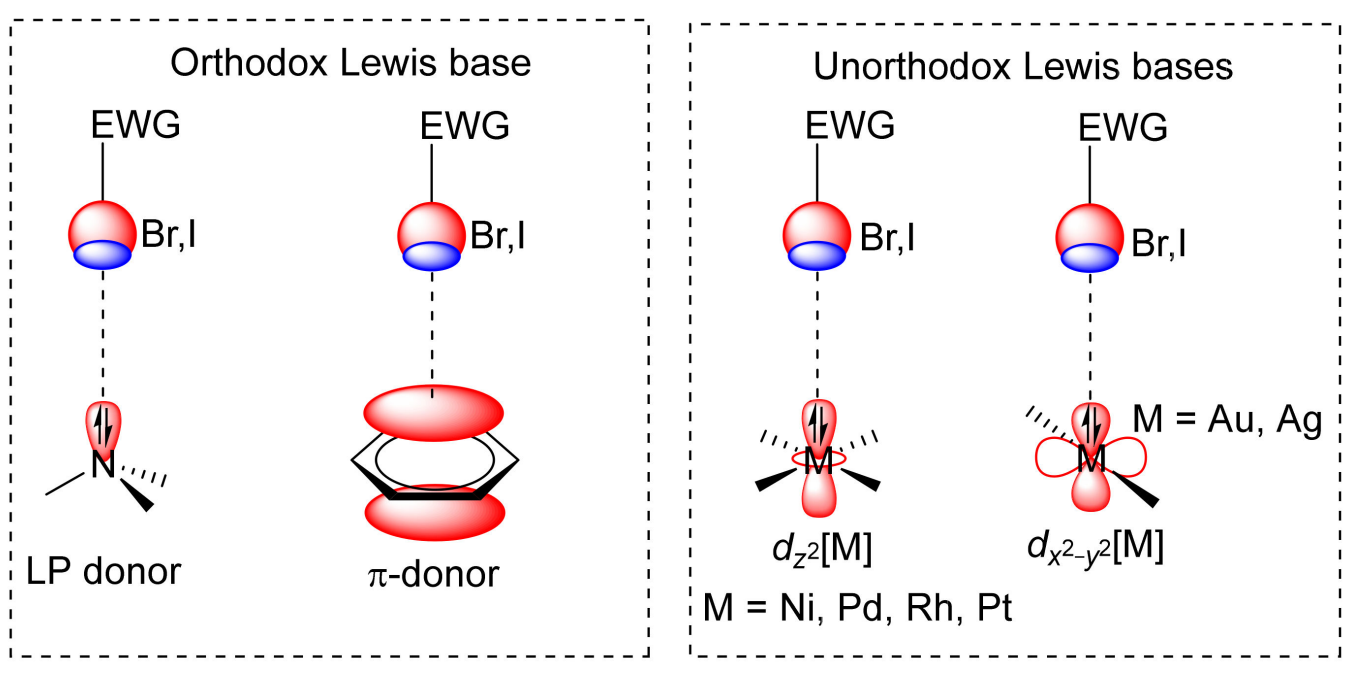

Figure 17. Schematic representation of orthodox (lone pair donors, $\pi$ systems) and unorthodox Lewis bases (square planar and linear metal complexes) establishing a HaB.

The ability of $\mathrm{Ni}$ (II) square planar complexes to form cocrystals with iodine derivatives has been studied in terms of donor-acceptor interactions [119,120]. Figure 18a shows the X-ray structure of a nitroguanidate $\mathrm{Ni}$ (II) complex (MEBXID [117]) that undergoes two simultaneous $\mathrm{Ni} \cdots \mathrm{I}$ HaBs with the co-crystallized 1,3,5-triiodotrifluorobenzene (FIB). The distance is significantly shorter than the sum of van der Waals radii $(\mathrm{Ni}+\mathrm{I}=3.61 \AA$ ) and the $\mathrm{C}-\mathrm{I} \cdots \mathrm{Ni}$ angle is far from linearity $\left(142.5^{\circ}\right.$, see Table 8$)$ but even farther from the ideal orientation expected for a semi-coordination bond $\left(\sim 90^{\circ}\right)$. The MEP surface plot (see Figure 18b) shows that the MEP is negative over the central Ni atom and that the minimum is found in the molecular plane between the $\mathrm{N}$ and $\mathrm{O}$ atoms of the nitroguanidate group. The value of MEP at the Ni indicates that this interaction has a predominant $\mathrm{HaB}$ nature that is further supported by a recent investigation, which has proven that the $\sigma$-hole at

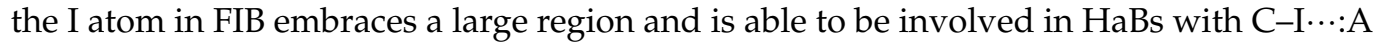
angles up to $105^{\circ}$ [121].
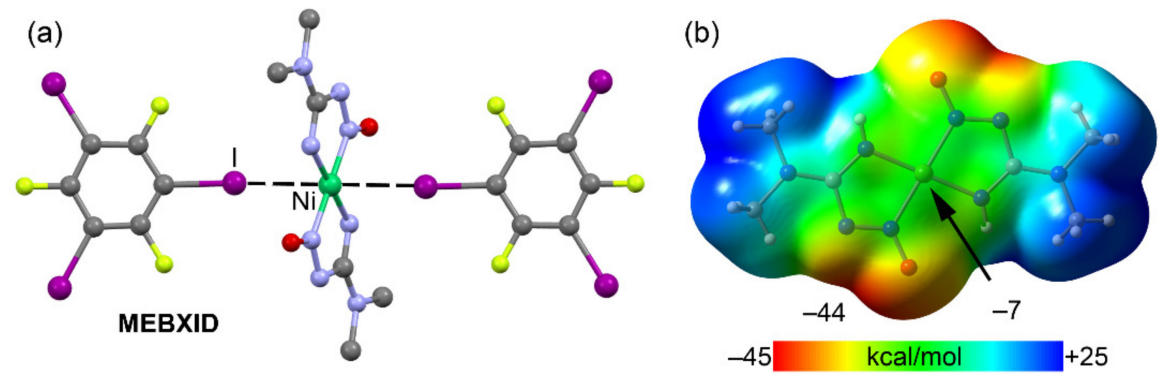

Figure 18. (a) Ball-and-stick representation of the X-ray solid-state structure of MEBXID in which the HaBs are indicated as dashed lines; (b) MEP surface of Ni(nitroguanidate) ${ }_{2}$ using the 0.001 a.u. isosurface (energies in $\mathrm{kcal} / \mathrm{mol}$ ). $\mathrm{H}$ atoms are omitted for clarity.

A Rh(I) complex of formula $\left[\mathrm{RhCl}_{2}(\mathrm{COD})\right]_{2}$ (COD $=1,5$-cyclooctadiene) has been recently synthesized and X-ray characterized to form co-crystals with several $\sigma$-hole iodine donors [122]. X-ray diffraction studies, in combination with extensive computations, indicate that the $d_{\mathrm{z}}{ }^{2}$-orbitals of two positively charged Rh(I) centers provide sufficient nucleophilicity to form three-center $\mathrm{HaB}$ with the $\sigma$-hole donors. The two metal centers function as an integrated $\mathrm{HaB}$ acceptor, providing assembly via metal-involving halogen bonding (see AMUPAC structure in Figure 19a). In this X-ray structure of $\left[\mathrm{RhCl}_{2}(\mathrm{COD})\right]_{2} \cdot\left(\mathrm{C}_{6} \mathrm{~F}_{4} \mathrm{I}_{2}\right)$, two iodine $\sigma$-hole donors interact with the $\mathrm{Rh}_{2} \mathrm{Cl}_{2}$ core of the complex above and below the $\mathrm{Rh}_{2} \mathrm{Cl}_{2}$ plane. The MEP surface represented in Figure $19 \mathrm{~b}$ confirms the nucleophilicity 
of the $\mathrm{Rh}_{2} \mathrm{Cl}_{2}$ cores $(-20$ and $-13 \mathrm{kcal} / \mathrm{mol}$ ). This unprecedented double $\mathrm{HaB}$ interaction is responsible for the propagation of the 1D-chain $\cdots\left[\mathrm{Rh}_{2} \mathrm{Cl}_{2}\right] \cdots \mathrm{I}\left(\mathrm{C}_{6} \mathrm{~F}_{4}\right) \mathrm{I} \cdots\left[\mathrm{Rh}_{2} \mathrm{Cl}_{2}\right] \cdots$ shown in Figure 19a.

(a)

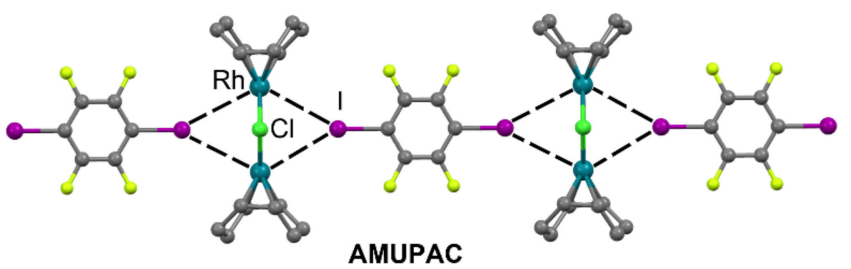

(b)

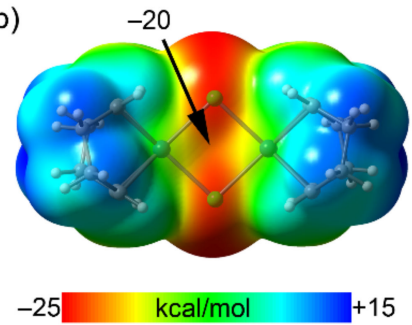

Figure 19. (a) Ball-and-stick representation of the X-ray solid-state structure of AMUPAC, in which HaBs are represented as dashed lines; (b) MEP surface of $\left[\mathrm{RhCl}_{2}(\mathrm{COD})\right]_{2}$ using the 0.001 a.u. isosurface (energies in $\mathrm{kcal} / \mathrm{mol}$ ). $\mathrm{H}$ atoms omitted for clarity.

It has also been reported in the literature that square-planar $\mathrm{Pd}(\mathrm{II})$ and $\mathrm{Pt}(\mathrm{II})$ complexes with halides as ligands have the interesting ability to participate in HaBs using both the halide and an $\mathrm{M}(\mathrm{II})$ center $(\mathrm{M}=\mathrm{Pd}$ and $\mathrm{Pt})$ as halogen bond acceptor [123-125]. The first experimental study of $\mathrm{Br}, \mathrm{I} \cdots d_{\mathrm{z}}{ }^{2}[\mathrm{Pd}] \mathrm{HaB}$ interactions was reported in 2018 by Boyarskiy et al. [125]. A series of new crystal structures trans-[ $\left.\mathrm{MCl}_{2}\left(\mathrm{NCNMe}_{2}\right)_{2}\right] \cdot 2 \mathrm{CHX}_{3}(\mathrm{M}=\mathrm{Pd}, \mathrm{Pt}$; $\mathrm{X}=\mathrm{Br}, \mathrm{I})$ were reported. Two of them are shown in Figures 20 and 21. It can be clearly observed that the C-Br (LIHMIB in Figure 20) and C-I (LIHMEX in Figure 21) bonds point to the M(II) metal center (see Table 8 for geometrical details).
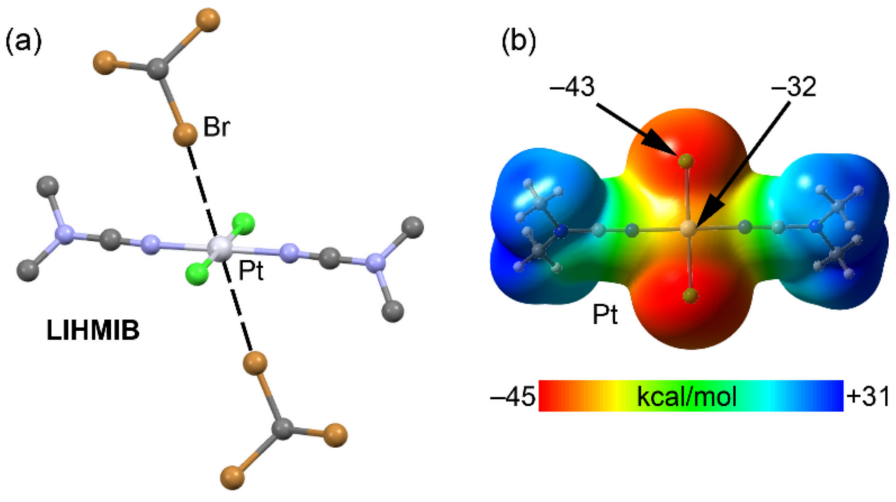

Figure 20. (a) Ball-and-stick representation of the X-ray solid-state structure of LIHMEX, in which $\mathrm{HaBs}$ are represented as dashed lines. The $\mathrm{HaBs}$ are represented using dashed lines. $\mathrm{H}$ atoms omitted for clarity; (b) MEP surface of $\mathrm{Pt}\left(\mathrm{NCNMe}_{2}\right)_{2} \mathrm{Cl}_{2}$ using the 0.001 a.u. isosurface (energies in $\mathrm{kcal} / \mathrm{mol}$ ).

(a)

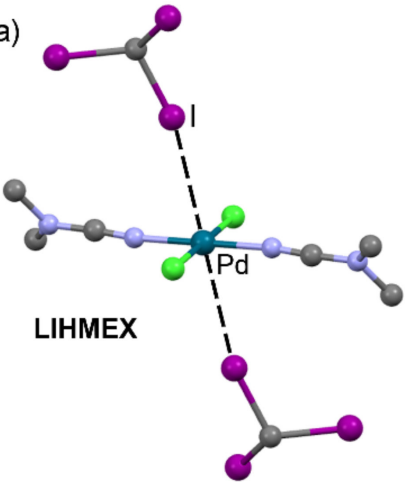

(b)

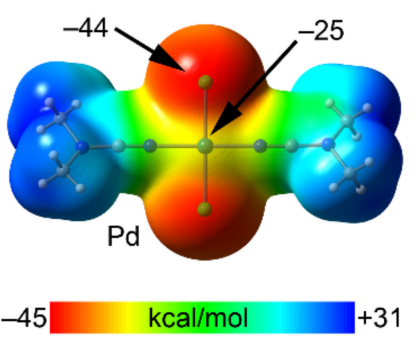

Figure 21. (a) Ball-and-stick representation of the X-ray solid-state structure of LIHMEX, where the $\mathrm{HaBs}$ are represented using dashed lines. H atoms omitted for clarity; (b) MEP surface of $\mathrm{Pd}\left(\mathrm{NCNMe}_{2}\right)_{2} \mathrm{Cl}_{2}$ using the 0.001 a.u. isosurface (energies in $\mathrm{kcal} / \mathrm{mol}$ ). 
These contacts were attributed to halogen bonds by using experimental data and theoretical calculations. In fact, the MEP surfaces shown in Figures 20b and 21b indicate that the MEP value above and below the M(II) atom is negative $(-32 \mathrm{kcal} / \mathrm{mol}$ for Pt and $-25 \mathrm{kcal} / \mathrm{mol}$ for $\mathrm{Pd}$ ), thus suitable for establishing $\sigma$-hole interactions as acceptor (see Table 8 for geometrical details).

Table 8. CSD codes, $\mathrm{HaB}$ donor $(\mathrm{Ha})$ and acceptor $(\mathrm{A})$ atoms, intermolecular distance $\left(\mathrm{d}_{\mathrm{Ha} \cdots \mathrm{A}}\right.$ in $\AA$ ), and $\mathrm{X}-\mathrm{HaB} \cdots \mathrm{A}(\mathrm{X}=\mathrm{N}, \mathrm{O}$, and $\mathrm{S})$ angle $\left(\angle\right.$ in $\left.^{\circ}\right)$.

\begin{tabular}{ccccc}
\hline CSD Code & Ha & $\mathbf{A}$ & $\mathbf{d}_{\mathbf{H a} \cdots \mathbf{A}}$ & \multicolumn{1}{c}{} \\
\hline MEBXID & $\mathrm{I}$ & $\mathrm{Ni}$ & 3.389 & 142.5 \\
\hline AMUPAC & $\mathrm{I}$ & $\mathrm{Rh}$ & 3.693 & 147.2 \\
\hline LIHMIB & $\mathrm{Br}$ & $\mathrm{Pt}$ & 3.365 & 165.9 \\
\hline LIHMEX & $\mathrm{I}$ & $\mathrm{Pd}$ & 3.512 & 164.9 \\
\hline
\end{tabular}

\subsection{Noble Gas Bonding}

In 2015, we provided [126], for the first time, theoretical evidence (by means of ab initio calculations) of the attractive interaction between a covalently bonded atom of group 18 (known as aerogens or noble gases) and an electron-rich atom (Lewis base or an anion). This was further confirmed by the existence of several X-ray structures of $\mathrm{Xe}(\mathrm{VI})$ derivatives in which this interaction drove the crystal packing formation. The original proposed name for this interaction was aerogen bonding, and it was described as a novel instance of $\sigma$-hole-based interactions. The term aerogen comes from the Greek "aeros" meaning air. In the field of chemistry, the term aerogen is commonly used to refer to any noble gas atom. However, in medicine, this term is usually defined as "a gas producing bacterium" [127]. Therefore, in this review, the term noble gas bond $(\mathrm{NgB})$ is used instead of aerogen bond to refer to those van der Waals contacts where the $\mathrm{Ng}$ atom acts as an electron acceptor in order to avoid confusion.

Table 9 summarizes the polarizabilities $(\alpha)$ and van der Waals radii of the noble gas elements from periods 2 to 5. The atomic $\alpha$ value increases from 6.3 a.u. in Ar to 19.9 a.u. in Xe. The polarizability values given in Table 9 for the $\mathrm{Ng}$ atoms are comparable to those reported for other elements of the p-block atom [128]. Additionally, the difference in the atomic polarizability between $\mathrm{Ng}$ from periods 3 to 5 is small ( x 2$)$, in line with the rest of the p-block elements. The MEP values at the $\sigma$-holes of the trioxide derivatives of the three $\mathrm{Ng}$ elements studied in this section are also given in Table 9, and the MEP surface of $\mathrm{XeO}_{3}$ is represented in Figure 22. They show the expected behavior, increasing from $37.7 \mathrm{kcal} / \mathrm{mol}$ in $\mathrm{ArO}_{3}$ to $52.7 \mathrm{kcal} / \mathrm{mol}$ in $\mathrm{XeO}_{3}$, parallel to the behavior observed for the atomic polarizability values.

Table 9. Atomic polarizabilities ( $\alpha$, a.u.) of noble gas ( $\mathrm{Ng}$ ) elements, van der Waals radii (in $\AA$ ), and $\sigma$-hole MEP values (in $\mathrm{kcal} / \mathrm{mol}$ ) of their tetrafluoride derivatives at the MP2/def2-TZVP level of theory. The data regarding $\mathrm{Ne}$ are not shown owing to the instability of the $\mathrm{NeO}_{3}$ compound.

\begin{tabular}{cccc}
\hline $\mathbf{N g}$ & $\mathbf{A}$ & $\mathbf{R}_{\mathbf{v d W}}$ & $\left.\mathbf{M E P}_{(\mathbf{N g}} \mathbf{3}\right)$ \\
\hline $\mathrm{Ar}$ & 6.3 & 1.88 & 37.7 \\
\hline $\mathrm{Kr}$ & 11.5 & 2.02 & 43.9 \\
\hline $\mathrm{Xe}$ & 19.9 & 2.16 & 52.7 \\
\hline
\end{tabular}

Figure 22 shows the MEP surface of $\mathrm{XeO}_{3}$ at the MP2/def2-TZVP level of theory. As is evident, there is a large and intense region of positive electrostatic potential covering the location of the $\mathrm{Ng}^{\prime}$ s lone pair. The value of MEP at the $\sigma$-hole becomes more positive on going from Ar to Xe, in a parallel way with their atomic polarizabilities. The MEP surfaces indicate that the anisotropy at the $\mathrm{Ng}$ atom is not easily noticeable in this set of molecules. 


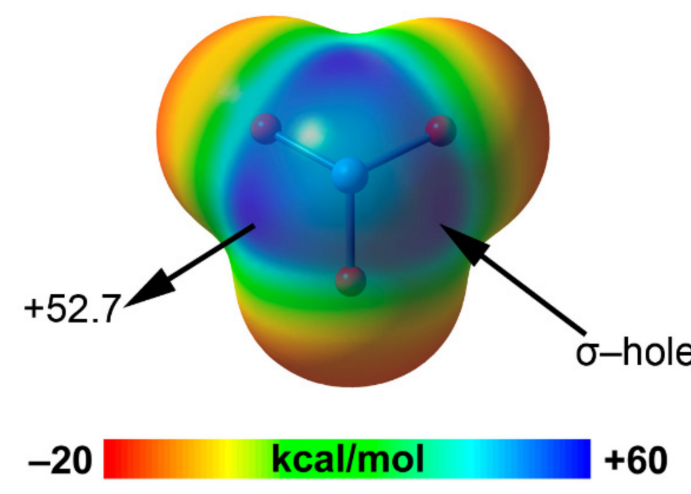

Figure 22. MEP surface (0.001 a.u.) of $\mathrm{XeO}_{3}$ (MP2/def2-TZVP). MEP energy at the selected point is given in $\mathrm{kcal} / \mathrm{mol}$.

\section{Xenon}

After our initial theoretical demonstration that $\mathrm{Xe}(\mathrm{VI})$ derivatives were able to participate in directional NCIs with electron-rich species such as Lewis bases and anions [126], several experimental and theoretical [129-131] studies have supported these initial findings and expanded the field of $\mathrm{NgBs}$. For instance, the $\mathrm{X}$-ray architecture of $\mathrm{XeO}_{3}$ shown in Figure 23 shows that each molecule is able to form three $\mathrm{Xe} \cdots \mathrm{O} \mathrm{NgBs}$ with surrounding $\mathrm{XeO}_{3}$ moieties (see Table 9 for details).

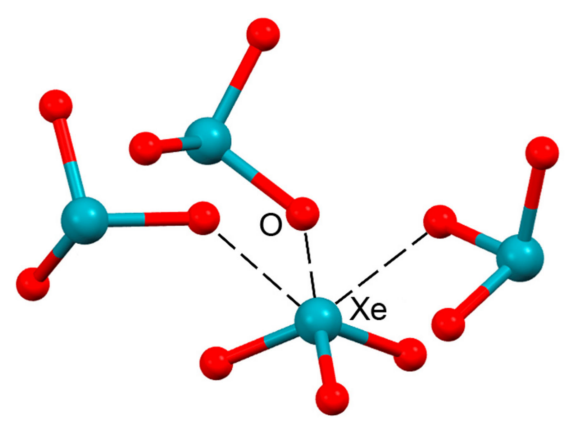

Figure 23. Ball-and-stick representation of the $\mathrm{X}$-ray structure of $\mathrm{XeO}_{3}$ retrieved from the ICSD (refcode ICSD253590). The NgBs are represented using dashed lines.

In this context, two additional interesting studies are worth highlighting. Firstly, Schrobilgen et al. reported the syntheses and $\mathrm{X}$-ray characterization of chlorine and bromine salts of general formula $\left[\mathrm{N}\left(\mathrm{C}_{2} \mathrm{H}_{5}\right)_{4}\right]_{3}\left[\mathrm{X}_{3}\left(\mathrm{XeO}_{3}\right)_{3}\right] \mathrm{X}=\mathrm{Cl}, \mathrm{Br}$ [132]. The $\mathrm{X}$-ray structure of these compounds exhibited interesting $\mathrm{NgBs}$ in their crystal packing. For instance, the KAZMEG structure shown in Figure 24a reveals the formation of three $\mathrm{Xe} \cdots \mathrm{Cl}^{-} \mathrm{NgBs}$. Interestingly, the arrangement of the three $\mathrm{Cl}^{-}$anions in the solid state coincides with the location of the three $\sigma$-holes. Second, in the study from Goettel et al. [133], a series of xenon trioxide alkylnitrile adducts were synthesized and the X-ray characterized. One of them is shown in Figure 24b (EZAKEX); it shows three $\mathrm{NgBs}$ involving two acetonitrile molecules and one $\mathrm{XeO}_{3}$ molecule (see Table 9 for geometrical details).

It is also worth mentioning the structure of $\left[\mathrm{N}\left(\mathrm{C}_{2} \mathrm{H}_{5}\right)_{4}\right]_{3}\left[\mathrm{X}_{3}\left(\mathrm{XeO}_{3}\right)_{3}\right]$ shown in Figure 25a (KAZLUV) [132] since it was the first example that presented a $\mathrm{Xe} \cdots \mathrm{Br} \mathrm{NgB}$ in the structure. Concretely, two $\mathrm{XeO}_{3}$ moieties are connected by three $\mathrm{Br}$ anions through the formation of six simultaneous $\mathrm{NgBs}$ (see Table 10 for geometrical details). In this assembly, the third molecule of $\mathrm{XeO}_{3}$ is also present and involved in two additional $\mathrm{Xe} \cdots \mathrm{Br}$ and one $\mathrm{Xe} \cdots \mathrm{O}$ $\mathrm{NgBs}$. Finally, Figure 25b also shows another X-ray structure (VIFKUT) in which the electron donor atom is an $\mathrm{sp}^{2}$-hybridized pyridine $\mathrm{N}$ atom [134]. 
(a)

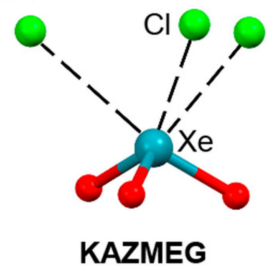

(b)

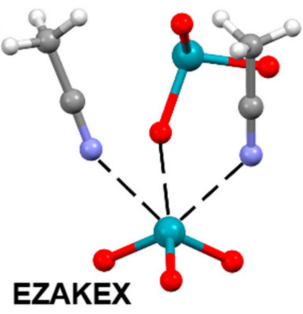

Figure 24. NgBs in the solid state of KAZMEG (a) and EZAKEX (b) structures. The NgBs are represented using dashed lines.

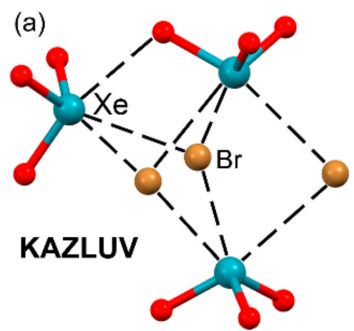

(b)

Figure 25. $\mathrm{NgBs}$ in the solid state of KAZLUV (a) and VIFKUT (b) structures. The NgBs are represented using dashed lines. $\mathrm{H}$ atoms omitted for clarity.

Table 10. CSD codes, $\mathrm{NgB}$ donor $(\mathrm{Ng})$ and acceptor $(\mathrm{A})$ atoms, intermolecular distance $\left(\mathrm{d}_{\mathrm{Ng} \cdots \mathrm{A}}\right.$ in $\AA$ ), and $\mathrm{X}-\mathrm{HaB} \cdots \mathrm{A}(\mathrm{X}=\mathrm{O})$ angle $\left(\angle \mathrm{in}^{\circ}\right)$.

\begin{tabular}{ccccc}
\hline CSD/ICSD Code & $\mathbf{N g}$ & $\mathbf{A}$ & $\mathbf{d}_{\mathbf{N g} \cdots \mathbf{A}}$ & \multicolumn{1}{c}{. } \\
\hline ICSD253590 & $\mathrm{Xe}$ & $\mathrm{O}$ & $2.80-2.90$ & $159-172$ \\
\hline KAZMEG & $\mathrm{Xe}$ & $\mathrm{Cl}$ & $3.070-3.101$ & $162-167.6$ \\
\hline EZAKEX & $\mathrm{Xe}$ & $\mathrm{O}$ & 2.758 & 164.4 \\
\hline KAZLUV & $\mathrm{Xe}$ & $\mathrm{Br}$ & $3.104-3.274$ & $158.5-165.8$ \\
\hline VIFKUT & $\mathrm{Xe}$ & $\mathrm{N}$ & $2.760-2.820$ & $170.4-173.8$ \\
\hline
\end{tabular}

\section{Concluding Remarks}

The data of MEP and polarizability data summarized in this review show that the polarizability of the p-block elements increases on moving from periods 2 to 5 , with large differences between periods 2 and 3. Moreover, the MEP values increase when descending in the group, similarly to the behavior observed for the polarizability. Moreover, tetrel and halogen elements exhibit larger MEP values than pnictogen, chalcogen, and noble gases. The $\sigma$-holes are more extended in heavier ChBs, PnBs, and $\mathrm{NgBs}$, thus explaining their poorer directionality, compared with TtBs and HaBs.

The X-ray structures shown in Sections 2.1-2.5 of this review are not intended to be comprehensive but to give significant experimental support to the fact that the elements from groups 14 to 18 have a strong tendency to establish directional TtB, PnB, ChB, HaB, and $\mathrm{NgB}$ interactions with Lewis bases or anions. Furthermore, these interactions play a relevant role in governing the solid-state architecture of the crystalline solids. These interactions, often unnoticed or simply identified as short or secondary contacts, are highly predictable and general. Therefore, they should be considered and used by the scientific community as a novel and efficient tool in several fields such as materials, catalysis, supramolecular chemistry, and crystal engineering.

Author Contributions: Conceptualization, A.F. and A.B.; methodology, A.F. and A.B.; software, A.F. and A.B.; investigation, A.F. and A.B.; writing—original draft preparation, A.B. and A.F., writing- 
review and editing, A.F. and A.B., visualization, A.F. and A.B., project administration, A.F.; funding acquisition, A.F. Both authors have read and agreed to the published version of the manuscript.

Funding: This research was funded by the MICIU/AEI of Spain (project PID2020-115637GB-I00 FEDER funds).

Institutional Review Board Statement: Not applicable.

Informed Consent Statement: Not applicable.

Data Availability Statement: Not applicable.

Conflicts of Interest: The authors declare no conflict of interest.

\section{References}

1. Pizzi, A.; Pigliacelli, C.; Bergamaschi, G.; Gori, A.; Metrangolo, P. Biomimetic engineering of the molecular recognition and self-assembly of peptides and proteins via halogenation. Coord. Chem. Rev. 2020, 411, 213242. [CrossRef]

2. Daolio, A.; Scilabra, P.; Terraneo, G.; Resnati, G. C( $\left.\mathrm{sp}^{3}\right)$ atoms as tetrel bond donors: A crystallographic survey. Coord. Chem. Rev. 2020, 413, 213265. [CrossRef]

3. Von der Heiden, D.; Vanderkooy, A.; Erdélyi, M. Halogen bonding in solution: NMR spectroscopic approaches. Coord. Chem. Rev. 2020, 407, 213147. [CrossRef]

4. Gill, H.; Gokel, M.R.; McKeever, M.; Negin, S.; Patel, M.B.; Yin, S.; Gokel, G.W. Supramolecular pore formation as an antimicrobial strategy. Coord. Chem. Rev. 2020, 412, 213264. [CrossRef]

5. Xu, Y.; Szell, P.M.J.; Kumar, V.; Bryce, D.L. Solid-state NMR spectroscopy for the analysis of element-based non-covalent interactions. Coord. Chem. Rev. 2020, 411, 213237. [CrossRef]

6. Wang, W.; Zhang, Y.; Jin, W.J. Halogen bonding in room-temperature phosphorescent materials. Coord. Chem. Rev. 2020, 404, 213107. [CrossRef]

7. Grabowski, S.J. Triel bond and coordination of triel centres-Comparison with hydrogen bond interaction. Coord. Chem. Rev. 2020, 407, 213171. [CrossRef]

8. Fromm, K.M. Chemistry of alkaline earth metals: It is not all ionic and definitely not boring! Coord. Chem. Rev. 2020, $408,213192$. [CrossRef]

9. Fourmigué, M.; Dhaka, A. Chalcogen bonding in crystalline diselenides and selenocyanates: From molecules of pharmaceutical interest to conducting materials. Coord. Chem. Rev. 2020, 403, 213084. [CrossRef]

10. Scheiner, S.; Michalczyk, M.; Zierkiewicz, W. Coordination of anions by noncovalently bonded $\sigma$-hole ligands. Coord. Chem. Rev. 2020, 405, 213136. [CrossRef]

11. Taylor, M.S. Anion recognition based on halogen, chalcogen, pnictogen and tetrel bonding. Coord. Chem. Rev. 2020, 413, 213270. [CrossRef]

12. Bauzá, A.; Frontera, A. $\sigma / \pi-$ Hole noble gas bonding interactions: Insights from theory and experiment. Coord. Chem. Rev. 2020, 404, 213112. [CrossRef]

13. Biot, N.; Bonifazi, D. Chalcogen-bond driven molecular recognition at work. Coord. Chem. Rev. 2020, 413, 213243. [CrossRef]

14. Cavallo, G.; Metrangolo, P.; Pilati, T.; Resnati, G.; Terraneo, G. Naming interactions from the electrophilic site. Cryst. Growth Des. 2014, 14, 2697-2702. [CrossRef]

15. Terraneo, G.; Resnati, G. Bonding Matters. Cryst. Growth Des. 2017, 17, 1439-1440. [CrossRef]

16. Desiraju, G.R.; Ho, P.S.; Kloo, L.; Legon, A.C.; Marquardt, R.; Metrangolo, P.; Politzer, P.; Resnati, G.; Rissanen, K. Definition of the halogen bond (IUPAC Recommendations 2013). Pure Appl. Chem. 2013, 85, 1711-1713. [CrossRef]

17. Aakeroy, C.B.; Bryce, D.L.; Desiraju, G.R.; Frontera, A.; Legon, A.C.; Nicotra, F.; Rissanen, K.; Scheiner, S.; Terraneo, G.; Metrangolo, P.; et al. Definition of the chalcogen bond (IUPAC Recommendations 2019). Pure Appl. Chem. 2019, 91, 1889-1892. [CrossRef]

18. Zahn, S.; Frank, R.; Hey-Hawkins, E.; Kirchner, B. Pnicogen bonds: A new molecular linker? Chem. Eur. J. 2011, 17, 6034-6038. [CrossRef] [PubMed]

19. Alkorta, I.; Elguero, J.; Frontera, A. Not only hydrogen bonds: Other noncovalent interactions. Crystals 2020, 10, 180. [CrossRef]

20. Bauzá, A.; Mooibroek, T.J.; Frontera, A. Tetrel Bonding Interaction: Rediscovered Supramolecular Force? Angew. Chem. Int. Ed. 2013, 52, 12317-12321. [CrossRef] [PubMed]

21. Daolio, A.; Pizzi, A.; Terraneo, G.; Frontera, A.; Resnati, G. $\sigma$-Holes Allow for Attractive Anion-anion Interactions Involving Perrhenate, Permanganate, and Pertechnetate Anions. ChemPhysChem 2021, 22. [CrossRef]

22. Daolio, A.; Pizzi, A.; Calabrese, M.; Terraneo, G.; Bordignon, S.; Frontera, A.; Resnati, G. Molecular Electrostatic Potential and Noncovalent Interactions in Derivatives of Group 8 Elements. Angew. Chem. Int. Ed. 2021, 60, 20723-20727. [CrossRef] [PubMed]

23. Bauzá, A.; Alkorta, I.; Elguero, J.; Mooibroek, T.J.; Frontera, A. Spodium Bonds: Noncovalent Interactions Involving Group 12 Elements. Angew. Chem. Int. Ed. 2020, 59, 17482-17487. [CrossRef] [PubMed]

24. Daolio, A.; Pizzi, A.; Terraneo, G.; Ursini, M.; Frontera, A.; Resnati, G. Anion·Anion Coinage Bonds: The Case of Tetrachloridoaurate. Angew. Chem. Int. Ed. 2021, 60, 14385-14389. [CrossRef] 
25. Frontera, A.; Bauzá, A. Regium $-\pi$ bonds: An Unexplored Link between Noble Metal Nanoparticles and Aromatic Surfaces. Chem. Eur. J. 2018, 24, 7228-7234. [CrossRef]

26. Terrón, A.; Buils, A.; Mooibroek, T.J.; Barceló, M.; García-Raso, A.; Fiol, J.J.; Frontera, A. Synthesis, X-ray characterization and regium bonding interactions of a trichlorido(1-hexylcytosine)gold(III) complex. Chem. Commun. 2020, 56, 3524-3527. [CrossRef]

27. Stenlid, J.H.; Johansson, A.J.; Brinck, T. $\sigma-$ Holes and $\sigma$-lumps direct the Lewis basic and acidic interactions of noble metal nanoparticles: Introducing regium bonds. Phys. Chem. Chem. Phys. 2018, 20, 2676-2692. [CrossRef]

28. Politzer, P.; Lane, P.; Concha, M.C.; Ma, Y.; Murray, J.S. An overview of halogen bonding. J. Mol. Model 2007, 13, 305-311. [CrossRef]

29. Metrangolo, P.; Resnati, G. Halogen bonding: A paradigm in supramolecular chemistry. Chem. Eur. J. 2001, 7, $2511-2519$. [CrossRef]

30. Kampes, R.; Zechel, S.; Hager, M.D.; Schubert, U.S. Halogen bonding in polymer science: Towards new smart materials. Chem. Sci. 2021, 12, 9275-9286. [CrossRef]

31. Metrangolo, P.; Meyer, F.; Pilati, T.; Resnati, G.; Terraneo, G. Halogen bonding in supramolecular chemistry. Angew. Chem. Int. Ed. 2008, 47, 6114-6127. [CrossRef]

32. Metrangolo, P.; Resnati, G. (Eds.) Halogen Bonding, Fundamentals and Applications; Springer: Berlin/Heidelberg, Germany, 2008.

33. Politzer, P.; Murray, J.S.; Clark, T. Halogen bonding: An electrostatically-driven highly directional noncovalent interaction. Phys. Chem. Chem. Phys. 2010, 12, 7748-7757. [CrossRef]

34. Erdélyi, M. Halogen bonding in solution. Chem. Soc. Rev. 2012, 41, 3547-3557. [CrossRef] [PubMed]

35. Beale, T.M.; Chudzinski, M.G.; Sarwar, M.G.; Taylor, M.S. Halogen bonding in solution: Thermodynamics and applications. Chem. Soc. Rev. 2013, 42, 1667-1680. [CrossRef] [PubMed]

36. Politzer, P.; Murray, J.S.; Clark, T. Halogen bonding and other $\sigma$-hole interactions: A perspective. Phys. Chem. Chem. Phys. 2013, 15, 11178-11189. [CrossRef]

37. Metrangolo, P.; Resnati, G. (Eds.) Halogen Bonding II Impact on Materials Chemistry and Life Sciences; Springer: Berlin/Heidelberg, Germany, 2015.

38. Gilday, L.C.; Robinson, S.W.; Barendt, T.A.; Langton, M.J.; Mullaney, B.R.; Beer, P.D. Halogen bonding in supramolecular chemistry. Chem. Rev. 2015, 115, 7118-7195. [CrossRef] [PubMed]

39. Cavallo, G.; Metrangolo, P.; Milani, R.; Pilati, T.; Priimagi, A.; Resnati, G.; Terraneo, G. The halogen bond. Chem. Rev. 2016, 116, 2478-2601. [CrossRef]

40. Mahmudov, K.T.; Kopylovich, M.N.; Guedes da Silva, M.F.C.; Pombeiro, A.J.L. Chalcogen bonding in synthesis, catalysis and design of materials. Dalton Trans. 2017, 46, 10121-10138. [CrossRef]

41. Gleiter, R.; Haberhauer, G.; Werz, D.B.; Rominger, F.; Bleiholder, C. From noncovalent chalcogen-chalcogen interactions to supramolecular aggregates: Experiments and calculations. Chem. Rev. 2018, 118, 2010-2041. [CrossRef]

42. Vogel, L.; Wonner, P.; Huber, S.M. Chalcogen bonding: An overview. Angew. Chem. Int. Ed. 2019, 58, 1880-1891. [CrossRef]

43. Scheiner, S. The pnicogen bond: Its relation to hydrogen, halogen, and other noncovalent bonds. Acc. Chem. Res. 2013, 46, 280-288. [CrossRef] [PubMed]

44. Del Bene, J.E.; Alkorta, I.; Elguero, J. The Pnicogen Bond in Review: Structures, Binding Energies, Bonding Properties, and Spin-spin Coupling Constants of Complexes Stabilized by Pnicogen Bonds. In Noncovalent Forces; Scheiner, S., Ed.; Springer: Heidelberg/Berlin, Germany, 2015; pp. 191-264.

45. Brammer, L. Halogen bonding, chalcogen bonding, pnictogen bonding, tetrel bonding: Origins, current status and discussion. Faraday Discuss. 2017, 203, 485-507. [CrossRef] [PubMed]

46. Politzer, P.; Murray, J.S.; Lane, P. $\sigma$-Hole bonding and hydrogen bonding: Competitive interactions. Int. J. Quantum. Chem. 2007, 107, 3046-3052. [CrossRef]

47. Zhu, S.; Xing, C.; Xu, W.; Jin, G.; Li, Z. Halogen bonding and hydrogen bonding coexist in driving self-assembly process. Cryst. Growth Des. 2004, 4, 53-56. [CrossRef]

48. Priimagi, A.; Cavallo, G.; Forni, A.; Gorynsztejn-Leben, M.; Kaivola, M.; Metrangolo, P.; Milani, R.; Shishido, A.; Pilati, T.; Resnati, G.; et al. Halogen Bonding versus Hydrogen Bonding in Driving Self-Assembly and Performance of Light-Responsive Supramolecular Polymers. Adv. Funct. Mater. 2012, 22, 2572-2579. [CrossRef]

49. Mukherjee, A.; Tothadi, S.; Desiraju, G.R. Halogen bonds in crystal engineering: Like hydrogen bonds yet different. Acc. Chem. Res. 2014, 47, 2514-2524. [CrossRef]

50. Scheiner, S. Forty years of progress in the study of the hydrogen bond. Struct. Chem. 2019, 30, 1119-1128. [CrossRef]

51. Corradi, E.; Meille, S.V.; Messina, M.T.; Metrangolo, P.; Resnati, G. Halogen Bonding versus Hydrogen Bonding in Driving Self-Assembly Processes. Angew. Chem. Int. Ed. 2000, 39, 1782-1786. [CrossRef]

52. Zingaro, R.A.; Hedges, M. Phosphine Oxide-Halogen Complexes: Effect on P-O and P-S Stretching Frequencies. J. Phys. Chem. 1961, 65, 1132-1138. [CrossRef]

53. Martire, D.E.; Sheridan, J.P.; King, J.W.; O'Donnell, S.E. Thermodynamics of Molecular Association. 9. An NMR Study of Hydrogen Bonding of $\mathrm{CHCl}_{3}$ and $\mathrm{CHBr}_{3}$ to Di-N-Octyl Ether, Di-NOctyl Thioether and Di-N-Octylmethylamine. J. Am. Chem. Soc. 1976, 98, 3101-3106. [CrossRef]

54. Dumas, J.-M.; Gomel, M.; Guerin, M. Molecular Interactions Involving Organic Halides. In Halides, Pseudo-Halides and Azides; John Wiley \& Sons, Ltd.: Chichester, UK, 1983; Volume 2, pp. 985-1020. 
55. Metrangolo, P.; Neukirch, H.; Pilati, T.; Resnati, G. Halogen Bonding Based Recognition Processes: A World Parallel to Hydrogen Bonding. Acc. Chem. Res. 2005, 38, 386-395. [CrossRef] [PubMed]

56. Pancholi, J.; Beer, P.D. Halogen bonding motifs for anion recognition. Coord. Chem. Rev. 2020, 416, 213281. [CrossRef]

57. Costa, P.J. The Halogen bond: Nature and applications. Phys. Sci. Rev. 2017, 2, 81-106. [CrossRef]

58. Szell, P.M.J.; Zablotny, S.; Bryce, D.L. Halogen bonding as a supramolecular dynamics catalyst. Nat. Commun. 2019, 10, 916. [CrossRef]

59. Wolters, L.P.; Schyman, P.; Pavan, M.J.; Jorgensen, W.L.; Bickelhaupt, F.M.; Kozuch, S. The many faces of halogen bonding: A review of theoretical models and methods. WIREs Comput. Molt. Sci. 2014, 4, 523-540. [CrossRef]

60. Project No. 2016-001-2-300. Available online: https:// iupac.org/project/2016-001-2-300 (accessed on 5 September 2021).

61. Bleiholder, C.; Gleiter, R.; Werz, D.B.; Köppel, H. Theoretical Investigations on Heteronuclear Chalcogen-Chalcogen Interactions: On the Nature of Weak Bonds between Chalcogen Centers. Inorg. Chem. 2007, 46, 2249-2260. [CrossRef]

62. Bleiholder, C.; Werz, D.B.; Köppel, H.; Gleiter, R. Theoretical investigations on chalcogen-Chalcogen interactions: What makes these nonbonded interactions bonding? J. Am. Chem. Soc. 2006, 128, 2666-2674. [CrossRef]

63. Politzer, P.; Murray, J.S. An overview of strengths and directionalities of noncovalent interactions: $\sigma$-holes and $\pi$-holes. Crystals 2019, 9, 165. [CrossRef]

64. Politzer, P.; Murray, J.S.; Clark, T.; Resnati, G. The $\sigma$-hole revisited. Phys. Chem. Chem. Phys. 2017, 19, 32166-32178. [CrossRef]

65. Gomila, R.M.; Mooibroek, T.J.; Frontera, A. A Combined Theoretical and CSD Perspective on $\sigma$-Hole Interactions with Tetrels, Pnictogens, Chalcogens, Halogens, and Noble Gases. In Hot Topics in Crystal Engineering; Elsevier: Amsterdam, The Netherlands, 2021. [CrossRef]

66. Alkorta, I.; Rozas, I.; Elguero, J. Molecular complexes between silicon derivatives and electron-rich groups. J. Phys. Chem. A 2001, 105, 743-749. [CrossRef]

67. Scheiner, S. Competition between a Tetrel and Halogen Bond to a Common Lewis Acid. J. Phys. Chem. 2021, 125, 308-316. [CrossRef]

68. Na, L.; Liu, J.; Li, Q.; Scheiner, S. Noncovalent bond between tetrel $\pi$-hole and hydride. Phys. Chem. Chem. Phys. 2021, 23, 10536-10544.

69. Chen, Y.; Wang, F. Intermolecular Interactions Involving Heavy Alkenes $\mathrm{H}_{2} \mathrm{Si}=\mathrm{TH}_{2}(\mathrm{~T}=\mathrm{C}, \mathrm{Si}, \mathrm{Ge}, \mathrm{Sn}, \mathrm{Pb})$ with $\mathrm{H}_{2} \mathrm{O}$ and $\mathrm{HCl}$ : Tetrel Bond and Hydrogen Bond. ACS Omega 2020, 5, 30210-30225. [CrossRef] [PubMed]

70. Alkorta, I.; Elguero, J.; Fruchier, A.; Macquarrie, D.J.; Virgili, A. Aminopropylsilanes versus silatranes: An experimental and theoretical study. J. Organomet. Chem. 2001, 625, 148-153. [CrossRef]

71. Grabowski, S.J. Lewis Acid Properties of Tetrel Tetrafluorides-The Coincidence of the $\sigma-H o l e$ Concept with the QTAIM Approach. Crystals 2017, 7, 43. [CrossRef]

72. Scilabra, P.; Kumar, V.; Ursini, M.; Resnati, G. Close contacts involving germanium and tin in crystal structures: Experimental evidence of tetrel bonds. J. Mol. Model. 2018, 24, 37. [CrossRef] [PubMed]

73. Bauzá, A.; Seth, S.K.; Frontera, A. Tetrel bonding interactions at work: Impact on tin and lead coordination compounds. Coord. Chem. Rev. 2019, 384, 107-125. [CrossRef]

74. Lukevics, E.; Arsenyan, P.; Belyakov, S.; Popelis, J.; Pudova, O. Cycloaddition reactions of nitrile oxides to silyl-and germylsubstituted thiophene-1,1-dioxides. Organometallics 1999, 18, 3187-3193. [CrossRef]

75. Villaescusa, L.A.; Lightfoot, P.; Morris, R.E. Synthesis and structure of fluoride-containing $\mathrm{GeO}_{2}$ analogues of zeolite double four-ring building units. Chem. Commun. 2002, 1, 2220-2221. [CrossRef]

76. Calogero, S.; Ganis, P.; Peruzzo, V.; Tagliavini, G.; Valle, G. X-ray and Mössbauer studies of tricyclohexyltin (IV) halides. The crystal structures of (cyclo- $\left.\mathrm{C}_{6} \mathrm{H}_{11}\right)_{3} \mathrm{SnX}(\mathrm{X}=\mathrm{F}, \mathrm{Br}$ and I). J. Organomet. Chem. 1981, 220, 11-20. [CrossRef]

77. Wang, J.-Q.; Kuang, D.-Z.; Zhang, F.-X.; Feng, Y.-L.; Xu, Z.-F. CCDC 211279: Experimental Crystal Structure Determination. 2004. [CrossRef]

78. Trujillo, C.; Sanchez-Sanz, G.; Alkorta, I.; Elguero, J. Halogen, chalcogen and pnictogen interactions in $\left(\mathrm{XNO}_{2}\right)_{2}$ homodimers $(\mathrm{X}=\mathrm{F}, \mathrm{Cl}, \mathrm{Br}, \mathrm{I})$. New J. Chem. 2015, 39, 6791-6802. [CrossRef]

79. Alkorta, I.; Elguero, J.; Grabowski, S.J. Pnicogen and hydrogen bonds: Complexes between $\mathrm{PH}_{3} \mathrm{X}^{+}$and $\mathrm{PH}_{2} \mathrm{X}$ systems. Phys. Chem. Chem. Phys. 2015, 17, 3261-3272. [CrossRef] [PubMed]

80. Esrafili, M.D.; Mohammadian-Sabet, F.; Baneshi, M.M. The dual role of halogen, chalcogen, and pnictogen atoms as Lewis acid and base: Triangular XBr:SHX: $\mathrm{PH}_{2} \mathrm{X}$ complexes $\left(\mathrm{X}=\mathrm{F}, \mathrm{Cl}, \mathrm{Br}, \mathrm{CN}, \mathrm{NC}, \mathrm{OH}, \mathrm{NH}_{2}\right.$, and $\left.\mathrm{OCH}_{3}\right)$. Int. J. Quantum Chem. 2015, 115, 1580-1586. [CrossRef]

81. Adhikari, U.; Scheiner, S. Sensitivity of pnicogen, chalcogen, halogen and H-bonds to angular distortions. Chem. Phys. Lett. 2012, 532, 31-35. [CrossRef]

82. Bauzá, A.; Quinonero, D.; Deyà, P.M.; Frontera, A. Halogen bonding versus chalcogen and pnicogen bonding: A combined Cambridge structural database and theoretical study. Cryst. Eng. Comm. 2013, 15, 3137-3144. [CrossRef]

83. Murray, J.S.; Lane, P.; Politzer, P. A predicted new type of directional noncovalent interaction. Int. J. Quantum Chem. 2007, 107, 2286-2292. [CrossRef]

84. Alkorta, I.; Sánchez-Sanz, G.; Elguero, J. Pnicogen Bonds between $\mathrm{X}-\mathrm{PH}_{3}\left(\mathrm{X}=\mathrm{O}, \mathrm{S}, \mathrm{NH}, \mathrm{CH}_{2}\right)$ and Phosphorus and Nitrogen Bases. J. Phys. Chem. A 2014, 118, 1527-1537. [CrossRef] 
85. Shukla, R.; Chopra, D. Characterization of N O non-covalent interactions involving $\sigma$-holes: "electrostatics" or "dispersion". Phys. Chem. Chem. Phys. 2016, 18, 29946-29954. [CrossRef] [PubMed]

86. Mokrai, R.; Jaie Barrett, J.; Apperley, D.C.; Benkő, Z.; Heift, D. Tweaking the Charge Transfer: Bonding Analysis of Bismuth(III) Complexes with a Flexidentate Phosphane Ligand. Inorg. Chem. 2020, 59, 8916-8924. [CrossRef] [PubMed]

87. Sarkar, S.; Pavan, M.S.; Guru Row, T.N. Experimental validation of 'pnicogen bonding' in nitrogen by charge density analysis. Phys. Chem. Chem. Phys. 2015, 17, 2330-2334. [CrossRef] [PubMed]

88. Joshi, P.R.; Ramanathan, N.; Sundararajan, K.; Sankaran, K. Evidence for phosphorus bonding in phosphorus trichloride-methanol adduct: A matrix isolation infrared and ab initio computational study. J. Phys. Chem. A 2015, 119, 3440-3451. [CrossRef] [PubMed]

89. Nelyubina, Y.V.; Korlyukov, A.A.; Lyssenko, K.A. Experimental charge density evidence for pnicogen bonding in a crystal of ammonium chloride. ChemPhysChem 2015, 16, 676-681. [CrossRef] [PubMed]

90. Andrea Gini, A.; Paraja, M.; Galmés, B.; Besnard, C.; Poblador-Bahamonde, A.I.; Sakai, N.; Frontera, A.; Matile, S. Pnictogenbonding catalysis: Brevetoxin-type polyether cyclizations. Chem. Sci. 2020, 11, 7086-7091. [CrossRef] [PubMed]

91. Scilabra, P.; Terraneo, G.; Resnati, G. Fluorinated elements of Group 15 as pnictogen bond donor sites. J. Fluor. Chem. 2017, 203, 62-67. [CrossRef]

92. Prokudina, Y.V.; Davydova, E.I.; Virovets, A.; Stöger, B.; Peresypkina, E.; Pomogaeva, A.V.; Timoshkin, A.Y. Structures and Chemical Bonding in Antimony(III) Bromide Complexes with Pyridine. Chem. Eur. J. 2020, 26, 16338-16348. [CrossRef]

93. Mahmudov, K.T.; Gurbanov, A.V.; Aliyeva, V.A.; Resnati, G.; Pombeiro, A.J.L. Pnictogen bonding in coordination chemistry. Coord. Chem. Rev. 2020, 418, 213381. [CrossRef]

94. Moaven, S.; Andrews, M.C.; Polaske, T.J.; Karl, B.M.; Unruh, D.K.; Bosch, E.; Bowling, N.P.; Cozzolino, A.F. Triple-Pnictogen Bonding as a Tool for Supramolecular Assembly. Inorg. Chem. 2019, 58, 16227-16235. [CrossRef]

95. Benz, S.; Poblador-Bahamonde, A.I.; Low-Ders, N.; Matile, S. Catalysis with pnictogen, chalcogen, and halogen bonds. Angew. Chem. Int. Ed. 2018, 57, 5408-5412. [CrossRef]

96. Lim, J.Y.C.; Beer, P.D. Sigma-hole interactions in anion recognition. Chem 2018, 4, 731-783. [CrossRef]

97. Hirai, M.; Cho, J.; Gabbaï, F.P. Promoting the Hydrosilylation of Benzaldehyde by Using a Dicationic Antimony-Based Lewis Acid: Evidence for the Double Electrophilic Activation of the Carbonyl Substrate. Chem. Eur. J. 2016, 22, 6537-6541. [CrossRef]

98. Qiu, J.; Unruh, D.K.; Cozzolino, A.F. Design, Synthesis, and Structural Characterization of a Bisantimony(III) Compound for Anion Binding and the Density Functional Theory Evaluation of Halide Binding through Antimony Secondary Bonding Interactions. J. Phys. Chem. A 2016, 120, 9257-9269. [CrossRef]

99. Haiges, R.; Vij, A.; Boatz, J.A.; Schneider, S.; Schroer, T.; Gerken, M.; Christe, K.O. First Structural Characterization of Binary AsIII and SbIII Azides. Chem. Eur. J. 2004, 10, 508-517. [CrossRef]

100. Deokar, P.; Leitz, D.; Stein, T.H.; Vasiliu, M.; Dixon, D.A.; Christe, K.O.; Haiges, R. Preparation and Characterization of Antimony and Arsenic Tricyanide and Their 2,2'-Bipyridine Adducts. Chem. Eur. J. 2016, 22, 13251-13257. [CrossRef]

101. Levason, W.; Light, M.E.; Maheshwari, S.; Reid, G.; Zhang, W. Unusual neutral ligand coordination to arsenic and antimony trifluoride. Dalton Trans. 2011, 40, 5291-5297. [CrossRef]

102. Burk, R.F. (Ed.) Selenium in Biology and Human Health; Springer: New York, NY, USA, 1994.

103. Saha, U.K. Selenium: A vital element in soil-pant-animal/human continuum. J. Agric. Sci. Bot. 2017, 1, 1-3.

104. Thomas, S.P.; Thomas, R.; Grønbech, T.B.E.; Bondesgaard, M.; Mamkhel, A.H.; Birkedal, V.; Iversen, B.B. Bandgap Tuning in Molecular Alloy Crystals Formed by Weak Chalcogen Interactions. J. Phys. Chem. Lett. 2021, 12, 3059-3065. [CrossRef] [PubMed]

105. Gritzenco, F.; Kazmierczak, J.C.; Anjos, T.; Sperança, A.; Peixoto, M.L.B.; Godoi, M.; Ledebuhr, K.N.B.; Brüning, C.A.; Zamin, L.L.; Godoi, B. Base-Free Synthesis and Synthetic Applications of Novel 3-(Organochalcogenyl) prop-2-yn-1-yl Esters: Promising Anticancer Agents. Synthesis 2021, 53, 2676-2688.

106. Vasiliu, M.; Peterson, K.A.; Dixon, D.A. Bond Dissociation Energies in Heavy Element Chalcogen and Halogen Small Molecules. J. Phys. Chem. A. 2021, 125, 1892-1902. [CrossRef] [PubMed]

107. Popa, R.A.; Licarete, E.; Banciu, M.; Silvestru, A. Organoselenium compounds containing pyrazole or phenylthiazole groups: Synthesis, structure, tin (IV) complexes and antiproliferative activity. Appl. Organomet. Chem. 2018, 32, e4252. [CrossRef]

108. Kimura, T.; Nakahodo, T.; Fujihara, H.; Suzuki, E. 4,5-Dicyano-3,6-diethylbenzo-1,2-diselenete, a Highly Stable 1,2-Diselenete: Its Preparation, Structural Characterization, Calculated Molecular Orbitals, and Complexation with Tetrakis (triphenylphosphine) palladium. Inorg. Chem. 2014, 53, 4411-4417. [CrossRef]

109. Xu, Y.; Kumar, V.; Bradshaw, M.J.Z.; Bryce, D.L. Chalcogen-Bonded Cocrystals of Substituted Pyridine N-Oxides and Chalcogenodiazoles: An X-ray Diffraction and Solid-State NMR Investigation. Cryst. Growth Des. 2020, 20, 7910-7920. [CrossRef]

110. Suzuki, T.; Fujii, H.; Yamashita, Y.; Kabuto, C.; Tanaka, S.; Harasawa, M.; Mukai, T.; Miyashi, T. Clathrate formation and molecular recognition by novel chalcogen-cyano interactions in tetracyanoquinodimethanes fused with thiadiazole and selenadiazole rings. J. Am. Chem. Soc. 1992, 114, 3034-3043. [CrossRef]

111. Fritz, S.; Ehm, C.; Lentz, D. Structure and Chemistry of $\operatorname{SeF}_{x}(C N)_{4-x}$ Compounds. Inorg. Chem. 2015, 54, 5220-5231. [CrossRef] [PubMed]

112. Garrett, G.E.; Gibson, G.L.; Straus, R.N.; Seferos, D.S.; Taylor, M.S. Chalcogen bonding in solution: Interactions of benzotelluradiazoles with anionic and uncharged Lewis bases. J. Am. Chem. Soc. 2015, 137, 4126-4133. [CrossRef] [PubMed]

113. Navarro-García, E.; Galmés, B.; Velasco, M.D.; Frontera, A.; Caballero, A. Anion Recognition by Neutral Chalcogen Bonding Receptors: Experimental and Theoretical Investigations. Chem. Eur. J. 2020, 26, 4706-4713. [CrossRef] [PubMed] 
114. Cozzolino, A.F.; Elder, P.J.W.; Vargas-Vaca, I. A survey of tellurium-centered secondary-bonding supramolecular synthons. Coord. Chem. Rev. 2011, 255, 1426-1438. [CrossRef]

115. Scheiner, S. Detailed comparison of the pnictogen bond with chalcogen, halogen, and hydrogen bonds. Int. J. Quantum Chem. 2013, 113, 1609-1620. [CrossRef]

116. Nziko, V.P.N.; Scheiner, S. Chalcogen Bonding between Tetravalent $\mathrm{SF}_{4}$ and Amines. J. Phys. Chem. A 2014, 118, 10849-10856. [CrossRef]

117. Subrahmanyan, I.; Aravamudan, G.; Rout, G.C.; Seshasayee, M. Synthesis, properties, and molecular structure of bis(thiobenzoatoS)tellurium(II), $\mathrm{C}_{14} \mathrm{H}_{10} \mathrm{O}_{2} \mathrm{~S}_{2} \mathrm{Te}(\mathrm{II})$. J. Crystal. Spect. Res. 1984, 14, 239-248. [CrossRef]

118. Neidlein, R.; Knecht, D.; Gieren, A.; Ruiz-Perez, C. Synthese und Röntgenstrukturanalyse des Phenanthro[9,10-c]-1,2,5telluradiazols. Naturforschung, Chem. Sci. 1987, 42, 84-90. [CrossRef]

119. Katlenok, E.A.; Haukka, M.; Levin, O.V.; Frontera, A.; Kukushkin, V.Y. Supramolecular Assembly of Metal Complexes by (Aryl) $\mathrm{dz}^{2}$ [PtII] Halogen Bond. Chem. Eur. J. 2020, 26, 7692-7701. [CrossRef] [PubMed]

120. Bikbaeva, Z.M.; Ivanov, D.M.; Novikov, A.S.; Ananyev, I.V.; Bokach, N.A.; Kukushkin, V.Y. Electrophilic-Nucleophilic Dualism of Nickel(II) toward Ni.I Noncovalent Interactions: Semicoordination of Iodine Centers via Electron Belt and Halogen Bonding via $\sigma$-Hole. Inorg. Chem. 2017, 56, 13562-13578. [CrossRef] [PubMed]

121. Rozhkov, A.V.; Eliseeva, A.A.; Baykov, S.V.; Galmés, B.; Frontera, A.; Kukushkin, V.Y. One-Pot Route to X-perfluoroarenes $(\mathrm{X}=\mathrm{Br}, \mathrm{I})$ Based on FeIII-Assisted C-F Functionalization and Utilization of These Arenes as Building Blocks for Crystal Engineering Involving Halogen Bonding. Cryst. Growth Des. 2020, 20, 5908-5921. [CrossRef]

122. Eliseeva, A.A.; Ivanov, D.M.; Rozhkov, A.V.; Ananyev, I.V.; Frontera, A.; Kukushkin, V.Y. Bifurcated Halogen Bonding Involving Two Rhodium (I) Centers as an Integrated $\sigma$-Hole Acceptor. JACS Au 2021, 1, 354-361. [CrossRef]

123. Gossage, R.A.; Ryabov, A.D.; Spek, A.L.; Stufkens, D.J.; van Beek, J.A.M.; van Eldik, R.; van Koten, G. Models for the Initial Stages of Oxidative Addition. Synthesis, Characterization, and Mechanistic Investigation of $\eta^{1}-\mathrm{I}_{2}$ Organometallic "Pincer" Complexes of Platinum. X-ray Crystal Structures of $\left[\mathrm{PtI}\left(\mathrm{C}_{6} \mathrm{H}_{3}\left\{\mathrm{CH}_{2} \mathrm{NMe}_{2}\right\}_{2}-2,6\right)\left(\eta^{1}-\mathrm{I}_{2}\right)\right]$ and exo-meso- $\left[\mathrm{Pt}\left(\eta^{1}-\mathrm{I}_{3}\right)\left(\eta^{1}-\mathrm{I}_{2}\right)\left(\mathrm{C}_{6} \mathrm{H}_{3}\left\{\mathrm{CH}_{2} \mathrm{~N}_{(\mathrm{t}-\mathrm{Bu}) \mathrm{Me}}\right\}_{2}-\right.\right.$ 2,6)]. J. Am. Chem. Soc. 1999, 121, 2488-2497.

124. Ivanov, D.M.; Kirina, Y.V.; Novikov, A.S.; Starova, G.L.; Kukushkin, V.Y. Efficient $\pi$-stacking with benzene provides $2 \mathrm{D}$ assembly of trans-[PtCl 2 (p-CF $\left.\left.\mathrm{C}_{6} \mathrm{H}_{4} \mathrm{CN}\right)_{2}\right]$. J. Mol. Struct. 2016, 1104, 19-23. [CrossRef]

125. Baykov, S.V.; Dabranskaya, U.; Ivanov, D.M.; Novikov, A.S.; Boyarskiy, V.P. Pt/Pd and I/Br Isostructural Exchange Provides

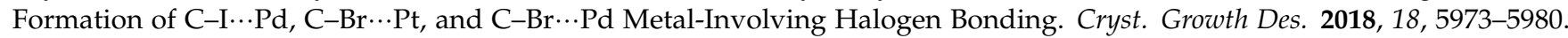
[CrossRef]

126. Bauzá, A.; Frontera, A. Aerogen Bonding Interaction: A New Supramolecular Force? Angew. Chem. Int. Ed. 2015, 54, 7340-7343. [CrossRef]

127. O'Toole, M. Miller-Keane Encyclopedia and Dictionary of Medicine, Nursing, and Allied Health, 7th ed.; Elsevier: Amsterdam, The Netherlands, 2003.

128. Bauzá, A.; Mooibroek, T.J.; Frontera, A. The bright future of unconventional $\sigma / \pi$-hole interactions. ChemPhysChem 2015, 16, 2496-2517. [CrossRef]

129. Miao, J.; Xiong, Z.; Gao, Y.J. The effects of aerogen-bonding on the geometries and spectral properties of several small molecular clusters containing $\mathrm{XeO}_{3}$. Condens. Matter Phys. 2018, 30, 444001. [CrossRef] [PubMed]

130. Esrafili, M.D.; Sadr-Mousavi, A. A computational study on the strength and nature of bifurcated aerogen bonds. Chem. Phys. Lett. 2018, 698, 1-6. [CrossRef]

131. Esrafili, M.D.; Kiani, H. Cooperativity between the hydrogen bonding and $\sigma$-hole interaction in linear $\mathrm{NCX} \cdots(\mathrm{NCH})_{\mathrm{n}=2-5}$ and $\mathrm{O}_{3} \mathrm{Z} \cdots(\mathrm{NCH})_{\mathrm{n}=2-5}$ complexes $(\mathrm{X}=\mathrm{Cl}, \mathrm{Br} ; \mathrm{Z}=\mathrm{Ar}, \mathrm{Kr})$ : A comparative study. Can. J. Chem. 2017, 95, 537-546. [CrossRef]

132. Goettel, J.T.; Haensch, V.G.; Schrobilgen, G.J. Stable chloro-and bromoxenate cage anions; $\left[\mathrm{X}_{3}\left(\mathrm{XeO}_{3}\right)_{3}\right]^{3-}$ and $\left[\mathrm{X}_{4}\left(\mathrm{XeO}_{3}\right)_{4}\right]^{4-}$ (X = Cl or Br). J. Am. Chem. Soc. 2017, 139, 8725-8733. [CrossRef] [PubMed]

133. Goettel, J.T.; Matsumoto, K.; Mercier, H.P.A.; Schrobilgen, G.J. Syntheses and structures of xenon trioxide alkylnitrile adducts. Angew. Chem. Int. Ed. 2016, 55, 13780-13783. [CrossRef] [PubMed]

134. Goettel, J.T.; Mercier, H.P.A.; Schrobilgen, G.J. $\mathrm{XeO}_{3}$ adducts of pyridine, 4-dimethylaminopyridine, and their pyridinium salts. J. Fluorine Chem. 2018, 121, 60-69. [CrossRef] 